\title{
Do Dominant Firms Provide More Training?
}

Christos Bilanakos*, Colin P. Green**, John S. Heywood† and Nikolaos Theodoropoulosł

* Department of Management Science and Technology, Athens University of Economics and Business, Greece; xmpilan@aueb.gr

** Department of Economics, Lancaster University, UK; c.p.green@lancaster.ac.uk

† Corresponding Author: Department of Economics, University of Wisconsin-Milwaukee, P.O. Box

413, Milwaukee WI 53201 USA; heywood@uwm.edu (414) 229-4310

‡ Department of Economics, University of Cyprus, Cyprus; n.theodoropoulos@ucy.ac.cy

\begin{abstract}
A canonical Cournot competition model shows that the profitability of training can increase as the number of competitors decreases. British establishment evidence from 1998, 2004 and 2011 confirms that firms in less competitive markets provide more formal training. This persists within three separate cross-sections and in two separate panel estimates. It persists with alternative measures of training, with alternative measures of market competition and in estimates designed to account for endogeneity. These results suggest that a dominant product market position, indeed, increases the incentives to invest in training.
\end{abstract}

JEL Codes: J24, J32

Acknowledgments: We acknowledge the Department of Trade and Industry, the Economic and Social Research Council, the Advisory, Conciliation and Arbitration Service and the Policy Studies Institute as the originators of the Workplace Employee Relations Survey data, and the Data Archive at the University of Essex as the distributor of the data, and thank the Office of National Statistics for providing the concentration indices. None of these organizations bears any responsibility for our analysis and interpretations of the data. We thank John Forth and Stephanie Freeth for data advice, and thank participants at the 2014 meetings of the Work Pensions Employment Group, an associate editor and three referees for comments. 


\section{Introduction}

Workplace training by employers creates important human capital (Acemoglu 1997) that directly matches the needs of firms and so becomes immediately valuable (Booth and Snower 1996). This training increases worker productivity and has been identified as reducing the marginal cost of production (Dearden et al. 2006; Moretti 2004; Zwick 2006), increasing wages and profitability (Jones et al. 2012; Konings and Vanormelingen, 2015; Lynch 1994) and generating positive externalities for the entire economy (Blundell et al. 1999). Understanding the determinants of such training is of clear importance. This paper concentrates on product market competition as an understudied determinant. We argue that employers' incentive to invest in training can decrease with the extent of product market competition and provide survey evidence from Britain that supports this prediction.

In contrast to the relatively clear-cut prediction on labor market competition (described in the next section), the relationship between product market competition and employer training appears highly dependent upon assumptions (see Wolter and Ryan, 2011 pages 533-534). While we argue that more competition reduces potential rents from training, competition may influence innovation (Aghion et al. 2005) and so the need for training. It may also influence union bargaining power and so negotiations over training (Boheim and Booth 2004). Indeed, the three theoretical contributions to date differ in their conclusions, predicting a positive, negative and ambiguous relationship between training and product market competition (Bassanini and Brunello 2011; Gersbach and Schmutzler 2012; Lai and Ng 2014). The existing empirical evidence remains similarly mixed, with some finding no effect of product competition on firm sponsored training (Picchio and Van Ours 2011; Görlitz and Stiebale 2011) and others finding a positive effect of competition (Lai and Ng 2014) and of product market deregulation (Bassanini et al. 2007; Bassanini and Brunello 2011) on training. 
We return to the issue, using a canonical model of Cournot competition to consider the effect of an exogenous change in the number of firms on the profitability of training investments. Decreasing the number of competitors generates off-setting influences but for illustrative functional forms the dominant influence is a scale or rent effect which increases per firm output and so the profitability of a cost reducing investment in training. Dominant firms provide more training.

We then use British establishment data to test the relationship between product market competition and training. Britain provides an interesting setting due to its relatively competitive product market and the view that it has increased the extent of employer provided training relative to other European countries. For example, contrast the relatively low estimates by Finegold and Soskice (1988) with more recent estimates by Arulampalam et al. (2004), Bassanini et al. (2007) and Boeri and van Ours (2013). Moreover, interest in training remains high in the UK because government programmes to increase employer provided training appear to have had only modest success in doing so (Abramovsky et al. 2011).

We examine several measures of training that reveal similar patterns but we focus on 'cross-training' which has been identified as particularly effective in lowering the cost of production as it uniquely reduces the cost associated with absence and turnover (Cappelli and Rogovsky 1994; Inman et al. 2005; Morita 2005). Critically for our purposes, cross-training often reflects the particular tasks and processes of a given firm and is almost exclusively firm-provided and more likely to be firm-specific (Cappelli and Rogovsky 1994). Thus, we estimate the determinants of cross-training as a firm-provided, cost reducing investment that is likely to have a large share of specific training. We demonstrate a robust negative relationship between product market competition and this form of training. Moreover, examining two other training measures reinforces this relationship by further demonstrating 
that dominant firms provide more training. The relationship also remains across a wide variety of specifications, for alternative measures of market dominance, in panel estimates and when attempting to account for the possible endogeneity of market dominance.

The remainder of the paper is organized as follows. Section 2 reviews the theoretical and the empirical literature with an eye toward motivating our contribution. Section 3 presents the theoretical model while Section 4 describes the data and the empirical methodology. Estimation results are presented in Section 5. Finally, Section 6 describes what has been learnt and discusses possible directions for future research.

\section{Reviewing Literature and Providing Motivation}

In describing the potential role for product market competition it is valuable to contrast it with the role of labor market competition. The starting point is Becker's (1964) prediction that employers will not invest in general training in competitive labor markets. The evidence that firms do provide general training (Katz and Ziderman 1990; Krueger 1993; Stevens 1994; Acemoglu and Pischke 1998; Booth and Bryan 2005) is explained by the presence of labor market frictions and wage compression (associated with less than competitive markets) that lead to skills becoming de facto firm-specific (Acemoglu and Pischke 1998; 1999). At an extreme, all industry-specific skills move from fully general to fully firm-specific as the market moves from perfectly competitive to monopsonistic (Manning 2003). In this view, increased labor market competitiveness reduces employers' overall incentives to invest in training. Indeed, Brunello and Gambarotto (2007) confirm empirically that employerprovided training is lower in more competitive labor markets.

As indicated in the introduction, the approaches to product market competition vary. Bassanini and Brunello (2011) assume monopolistic competition and explore an increase in product market competition resulting from deregulation that reduces barriers to entering the 
market. In their setting, deregulation increases training. While it has a negative impact (or a 'rent effect') by decreasing profits per unit of output associated with training, this is more than offset by a positive 'business stealing effect'. The increased number of firms increases the price elasticity of demand increasing the positive impact of training on a firm's individual demand and output.

Gersbach and Schmutzler (2012) model oligopolistic competition with two firms producing a differentiated good and suggest that increased competition decreases training. Here, competition in the product market is defined to be intense (weak) if a firm's marginal profit from attracting an additional trained worker is higher (lower) than the marginal profit from being in a symmetric training equilibrium rather than in a no-training equilibrium. Training is assumed to be industry-specific: it increases productivity not only with the current employer but also with other firms operating in the same industry. If competition is weak, an equilibrium with training exists provided training costs are not too high and a wage compression condition holds in the labor market. On the other hand, an equilibrium without training exists if competition in the product market is intense. Intuitively, weak competition reduces the probability of a worker leaving her current employer and thus strengthens the latter's incentives to invest in human capital. In essence, the increase in competition makes the industry-specific capital increasingly general. In this way, it mimics some of the logic from the discussion on labor market competition.

A different approach has been followed by Lai and Ng (2014), who assume that each firm has private information about product quality and that training serves as a signal of high quality. An increase in product market competition reduces the probability of survival for all firms but disproportionately so for firms of bad quality. This lowers the expected return of investment and tends to reduce training. At the same time, however, it increases good firms' incentives to use training as a signal of their quality in order to differentiate themselves from 
bad firms. Therefore, the overall impact of product market competition on training is ambiguous and depends on the relative strength of these two opposing effects.

While these three papers make predictions of a positive, negative and ambiguous association between training and product market competition, they employ starkly different models and emphasize different points. Indeed, the very definition of product market competition differs. It is seen as an exogenous reduction in barriers to entry, as increased substitutability of differentiated products or as an increased probability of failure in a signaling model.

We examine canonical Cournot competition with homogenous products and consider an exogenous increase in the number of firms. Vives (2008) identifies this as a "workhorse" model for examining the influence of competitive pressure. In his own theoretical work on competitive pressures and innovation, he stresses that when the outputs of the firms are strategic substitutes, the importance of the scale or rent effect typically results in a reduction in expenditures on cost reducing innovation as the number of firms increases (Vives 2008, p. 423). It is precisely this dynamic that interests us in the case of training and so we employ this model. We also emphasize the importance of this effect according to which increased competition reduces per firm output and so the profitability of a cost reducing investment in training with the consequence that dominant firms typically provide more training. It is this hypothesis that we test.

The empirical evidence on training and market structure to date has been mixed. To our knowledge there are six papers that examine the effect of product market competition on training. Two papers find no effect of product market competition on training, one using Dutch worker-manufacturing firm data on firm sponsored training (Picchio and van Ours 2011), the other using German establishment data (Görlitz and Stiebale 2011). In contrast, Lai and Ng (2014) find a strong and positive effect of competition on training using Canadian 
longitudinal matched employer-employee data. Similarly, Bassanini et al. (2007) and Bassanini and Brunello (2011) demonstrate a positive relationship between training and product market deregulation in Europe. Finally, Autor (2001) provides evidence that temporary help service firms that face more competition for supplying their product, agency workers, provide more computer training. These studies use a variety of definitions of training (several of which seem clearly not firm-specific) and, as in most applications the exact measure of training is likely to be consequential (Barron et al. 1997). They also differ dramatically in the measures of product market competition and in their institutional settings.

We provide the first empirical test that focuses attention on the relationship between product market competition and formal training in Britain. We use establishment data to examine several training measures but emphasize a unique question that measures the share of workers who are cross-trained. These are workers trained to perform one or more jobs other than their own. Cross-training has been identified as particularly effective in lowering the cost of production by uniquely reducing the cost associated with absence and turnover (Cappelli and Rogovsky 1994; Inman et al. 2005; Morita 2005). Cross-training also creates a more flexible workforce that can more readily respond to changes in technology and to peak loads of demand (Heywood et al. 2008). Moreover, Carmichael and MacLeod (1993) show how such training makes employment security pledges more credible generating the likelihood of compensating and cost saving wage reductions. Hopp et al. (2004) identify empirically the substantial cost reductions from cross-training in labor intensive industries while Slomp and Molleman (2002) show that such training improves the effectiveness and cohesion of work teams.

Critical for our purposes, cross-training reflects the particular tasks and processes of a given firm and is almost exclusively firm-provided and a large share of it is likely to be firmspecific (Cappelli and Rogovsky 1994). It becomes increasingly firm-specific not only 
because training for an additional job will have additional specific components but because, as Lazear (2009) emphasizes, unique mixtures of even general training become increasingly firm-specific. Cross-training then generates a particular "skill-weighting" that is often highly firm-specific (Lazear 2009). As such, it is likely to increase the expected tenure of workers and so lower recruiting and other training costs that are quasi-fixed (Munasinghe and O'Flaherty 2005). After our theoretical presentation, we estimate the determinants of training focusing on the role of product market competition. As mentioned, while we examine crosstraining, which we think it is likely to contain large specific elements, we supplement this with two other broader measures. We demonstrate a robust relationship suggesting that product market dominance is associated with increased training and increased cross-training in particular.

\section{Theoretical Model}

We assume the cost of training increases with the proportion of workers trained within the firm. Increasing the proportion of trained workers reduces per unit production cost and ultimately generates more total profit when a firm has greater output. As a consequence, a more competitive market structure has more firms each producing less and so facing weaker incentives to train when the negative "rent effect" dominates the positive "business-stealing effect” associated with training. We present a very general model showing these off-setting effects and in the Appendix present a standard example where the "rent effect" is indeed dominant.

\subsection{Setup}

Consider $n \geq 2$ identical firms (indexed $j=1, \ldots, n$ ) producing a homogeneous good. The quantity produced by firm $j$ is $q_{j}$ and $q=\sum_{i=1}^{n} q_{i}$. The price is given by the inverse demand 
function $p(q)$ with $p^{\prime}(q)<0$. Each firm formally trains a proportion $I_{j} \in[0,1]$ of its workforce. The cost of training for firm $j$ is given by the strictly convex function $g\left(I_{j}\right)$ with $g^{\prime}\left(I_{j}\right)>0$ and $g^{\prime \prime}\left(I_{j}\right)>0$. We follow Gersbach and Schmultzer (2012) by assuming that training reduces the marginal cost of production. ${ }^{1}$ We capture this in the cost function $C\left(q_{j}, I_{j}\right)$ with $\partial C / \partial q_{j}>0, \partial^{2} C / \partial q_{j}^{2} \geq 0, \partial C / \partial I_{j}<0$ and $\partial^{2} C / \partial I_{j} \partial q_{j}<0$ which implies that the marginal cost of production decreases with training. Thus, firm $j$ 's overall cost function is:

$$
f\left(q_{j}, I_{j}\right)=C\left(q_{j}, I_{j}\right)+g\left(I_{j}\right)
$$

In order to focus on the effect of product market competition, we suppress the labor market by normalizing the wage to zero. This is arbitrary but assumes that the firm is a monopsonist vis-à-vis its workforce and captures all benefits associated with formal training. The worker's outside option is not improved with training. Each firm $j$ 's profit is:

$$
\Pi_{j}=p q_{j}-C\left(q_{j}, I_{j}\right)-g\left(I_{j}\right)
$$

\subsection{Subgame Perfect Equilibrium}

We assume that in stage 1 , firms $j=1, \ldots, n$ simultaneously choose training $\boldsymbol{I}_{\boldsymbol{j}}$ and in stage 2 , firms $j=1, \ldots, n$ simultaneously choose quantity $\boldsymbol{q}_{j}$ (Cournot quantity competition). In this setting, the extent of competition in the product market increases with the number $(n)$ of firms. The equilibrium is identified by backwards induction.

\footnotetext{
${ }^{1}$ This formulation is typically equivalent to the assumption that training increases the marginal productivity of labor (see Bassanini and Brunello 2011). Indeed, solving the cost-minimization problem of firm $\mathrm{j}$ under the latter assumption yields compensated factor demand functions showing that the amount of labor required to produce an additional unit of output decreases with training. This directly translates into a marginal cost function that also decreases with training intensity, as in our model. We thank an anonymous referee for pointing out the general equivalence of these alternative assumptions.
} 
In stage 2, each firm chooses $q_{j}$ so as to maximize profits taking as given the quantities of other firms and the investment levels from the first stage. This yields the optimization problem $\max _{\left\{q_{j}\right\}} \Pi_{j}=p(q) q_{j}-C\left(q_{j}, I_{j}\right)-g\left(I_{j}\right)$ s.t. $q_{j} \geq 0$.

The first-order condition for maximization is:

$$
\partial \Pi_{j} / \partial q_{j}=p(q)+p^{\prime}(q) q_{j}-\partial C / \partial q_{j}=0
$$

The second-order condition is:

$$
\partial^{2} \Pi_{j} / \partial q_{j}^{2}=2 p^{\prime}(q)+p^{\prime \prime}(q) q_{j}-\partial^{2} C / \partial q_{j}^{2} \leq 0
$$

Solving the first-order condition generates firm $j$ 's best-response function $q_{j}\left(q_{-j}\right)$, where $q_{-j}=\left(q_{1}, \ldots, q_{j-1}, q_{j+1}, \ldots, q_{n}\right)$ and $\partial q_{j} / \partial q_{i}<0$ for all $i \neq j$. The combination of quantity choices $\left(q_{j}^{C}, q_{-j}^{C}\right)$ is a Cournot-Nash equilibrium if and only if $q_{j}^{C}=q_{j}\left(q_{-j}^{C}\right)$ for all $j=1, \ldots, n$. Hence we get the second-stage equilibrium quantity $q_{j}^{C}\left(I_{j}, I_{-j}\right)$ produced by each firm $j$ and the associated price $p^{C}\left(I_{j}, I_{-j}\right)$, where $I_{-j}=\left(I_{1}, \ldots, I_{j-1}, I_{j+1}, \ldots, I_{n}\right)$. From Varian (1992, pp. 490-1) we know that the sign of $\partial q_{j}^{C} / \partial I_{j}$ is the same as the sign of $\partial^{2} \Pi_{j} / \partial q_{j} \partial I_{j}$ under the second-order condition. Since $\partial^{2} \Pi_{j} / \partial q_{j} \partial I_{j}=-\partial^{2} C / \partial q_{j} \partial I_{j}>0$, we also conclude that $\partial q_{j}^{C} / \partial I_{j}>0$

In stage 1, firms simultaneously choose the training levels taking as given the levels of other firms and anticipating the second-stage outcome derived above. The profit maximization problem for firm $j$ is:

$$
\max _{\left\{I_{j}\right\}} \Pi_{j}^{C}\left(I_{j}, I_{-j}\right)=p^{C}\left(I_{j}, I_{-j}\right) \cdot q_{j}^{C}\left(I_{j}, I_{-j}\right)-C\left(q_{j}^{c}\left(I_{j}, I_{-j}\right), I_{j}\right)-g\left(I_{j}\right) \text { s.t. } 0 \leq I_{j} \leq 1
$$

The case of boundary solutions is considered in the Appendix but we assume here that $I_{j} \in(0,1)$. The first-order condition for maximization is: 


$$
\frac{\partial \Pi_{j}^{C}}{\partial I_{j}}=\frac{\partial p^{C}}{\partial I_{j}} \cdot q_{j}^{C}-\frac{\partial C}{\partial I_{j}}+\left(p^{C}-\frac{\partial C}{\partial q_{j}}\right) \cdot \frac{\partial q_{j}^{C}}{\partial I_{j}}-\frac{\partial g}{\partial I_{j}}=0
$$

An increase in firm $j$ 's investment level reduces price by $\partial p^{C} / \partial I_{j}$ but, at the same time, decreases firm $j$ 's production cost by $\partial C / \partial I_{j}$. Furthermore, an increase in $I_{j}$ increases firm $j$ 's quantity $q_{j}$. The term $\left(p^{C}-\partial C / \partial q_{j}\right) \cdot\left(\partial q_{j}^{C} / \partial I_{j}\right)$ is the marginal benefit associated with this increase in sales. Finally, the term $\partial g / \partial I_{j}$ is the marginal cost of investment in training. After imposing symmetry $\left(I_{i}=I_{j}\right.$ for all $\left.i, j=1, \ldots, n\right)$ we get $q_{j}^{C}=q_{j}^{C S}, p^{C}=p^{C S}$ and solve for the equilibrium level of training $\left(I_{j}^{*}\right)$.

\subsection{The Impact of Product Market Competition on Training Intensity}

We are interested in the effect of product market competition on the equilibrium level of training. The sign of $\partial I_{j}^{*} / \partial n$ is the same as the sign of $\partial^{2} \Pi_{j}^{C} / \partial I_{j} \partial n$, where:

$$
\frac{\partial^{2} \Pi_{j}^{C}}{\partial I_{j} \partial n}=\frac{\partial p^{C S}}{\partial n} \cdot \frac{\partial q_{j}^{C}}{\partial I_{j}}+\frac{\partial p^{C}}{\partial I_{j}} \cdot \frac{\partial q_{j}^{C S}}{\partial n}-\frac{\partial^{2} C}{\partial I_{j} \partial n}+q_{j}^{C S} \cdot \frac{\partial^{2} p^{C}}{\partial I_{j} \partial n}+\left(p^{C S}-\frac{\partial C}{\partial q_{j}}\right) \cdot \frac{\partial^{2} q_{j}^{C}}{\partial I_{j} \partial n}
$$

The first three terms of this expression represent the negative "rent effect" and the last two terms represent the positive "business-stealing effect" associated with training. In this very general setting, a larger number of firms in the market can either increase or decrease training depending on the relative strength of these two effects. Therefore, our main question concerning the overall impact of competition on training is ultimately an empirical one. Before proceeding with the empirical estimations, however, we use a specific example which enables us to write the two offsetting effects in a more compact and intuitive form as well as to reach a reduced-form equilibrium solution. This solution illustrates the case where the rent 
effect is stronger than the business-stealing effect. ${ }^{2}$ In particular, we consider a linear inverse demand $p(q)=a-q$, a training cost function $g\left(I_{j}\right)=\theta I_{j}^{2} / 2$ and a production cost function $C\left(q_{j}, I_{j}\right)=\varphi\left(I_{j}\right) q_{j}=\left[c-(c-\gamma) I_{j}\right] q_{j}$ with $a>c>\gamma>0$ and $\theta>0$. The derivation of the equilibrium associated with this specific case is in the Appendix where it can be seen that equation (6) can be written as:

$$
\begin{aligned}
& \frac{\partial^{2} \Pi_{j}^{C}}{\partial I_{j} \partial n}=2 \cdot\left[\frac{\partial q_{j}^{C S}}{\partial n} \cdot \frac{\partial q_{j}^{C}}{\partial I_{j}}+q_{j}^{C S} \cdot \frac{\partial^{2} q_{j}^{C}}{\partial I_{j} \partial n}\right]=2 \cdot\left[-\frac{a-c+(c-\gamma) I_{j}^{*}}{(n+1)^{2}} \cdot \frac{n(c-\gamma)}{n+1}+\frac{a-c+(c-\gamma) I_{j}^{*}}{n+1} \cdot \frac{c-\gamma}{(n+1)^{2}}\right]= \\
& =\frac{2(c-\gamma)\left[a-c+(c-\gamma) I_{j}^{*}\right](1-n)}{(n+1)^{3}}<0 \text { for all } n>1
\end{aligned}
$$

The term $\left(\partial q_{j}^{C S} / \partial n\right) \cdot\left(\partial q_{j}^{C} / \partial I_{j}\right)$ captures the negative "rent effect" which shows that increasing $n$ reduces each firm's sales and, thereby, reduces the marginal profit of investment in training. The positive "business-stealing effect" is captured by the term $q_{j}^{C S} \cdot\left(\partial^{2} q_{j}^{C} / \partial I_{j} \partial n\right)$ showing that a higher number of firms implies a higher increase of individual output associated with an additional percentage point of training. For the specific functions considered in the Appendix, the negative "rent effect" dominates the positive "businessstealing” effect, implying that greater competition decreases the incentive to invest in training (see Proposition A1). This result motivates our empirical testing as it suggests that dominant firms provide more training.

\section{Data and Empirical Methodology}

We draw data from the 1998, 2004 and 2011 cross-sections of the Workplace Employment Relations Survey (WERS). Associated with these three cross-sections are two smaller panel surveys, one for 1998 to 2004 and one for 2004 to 2011. We examine our fundamental

\footnotetext{
${ }^{2}$ Indeed, our efforts to use simple functional forms to find a counter-example in which the opposite is true have not been successful despite the general result that such counter-examples can exist.
} 
hypothesis in all five data sources with the second two allowing us to control for establishment specific fixed effects. ${ }^{3}$ We examine a wide variety of specifications including alternative sets of control variables and alternative measures of both training and market dominance. We also attempt to control for the potential endogeneity of market dominance in estimates that also control for establishment fixed effects. This wide variety of estimates consistently demonstrates that dominant firms provide more training.

\subsection{WERS Data}

The 1998, 2004 and 2011 cross-sections are the fourth, fifth and sixth instalments of a Government funded survey of British workplaces. In each year the sample of workplaces was randomly drawn from the Interdepartmental Business Register, considered to be the highest quality available sampling frame. The surveys are stratified by workplace size and industry with larger workplaces and some industries overrepresented (Chaplin et al. 2005). As a consequence, all estimates are weighted to be representative of the sampling population. The survey comprises three main sections; the 'Management Questionnaire' (a face-to-face interview with the most senior manager with day-to-day responsibility for personnel matters), the 'Worker Representative Questionnaire' and the 'Employee Questionnaire'. We rely exclusively on the Management Questionnaire as it provides information on three measures of training and product market competition. The survey population is all British workplaces except private households and those in primary industries.

The response rates for 1998, 2004 and 2011 were 80\%, 64\% and 46\% yielding 2,191, 2,295 and 2,680 establishments respectively. Response rates are decreasing through time reflecting prevailing trends in business surveys (see van Wanrooy et al. 2013). The 1998 WERS interviewed workplaces with 10 or more employees, while the 2004 and 2011 WERS

\footnotetext{
${ }^{3}$ Workplaces are followed up only once and 1998 observations cannot be followed into 2011.
} 
surveys interviewed workplaces with 5 or more employees. To ensure comparable estimates across years we limit attention to establishments with ten or more employees. We also exclude establishments not in the trading sector (government and non-profit establishments) and those missing data on the critical dependent variables measuring training. The resulting sample sizes are 1,464, 1,263, and 1,297 for the 1998, 2004 and 2011 respectively.

The 1998-2004 Panel Survey returned in 2004 to a random selection of workplaces in the 1998 cross-section. The follow-up survey, with a response rate of 77 per cent, yielded a sample of 956 continuing establishments. Our sample restrictions reduce this number but retain 470 establishments (940 observations) observed in both 1998 and in 2004. The 2011 WERS followed 989 workplaces that also participated in the 2004 which, after our sample restrictions, yielded 355 establishments (710 observations) observed in both 2004 and 2011.

The surveys are extremely attractive for our purpose as they identify training, crosstraining in particular, and product market competition while providing a wide range of relevant employer characteristics that serve as important controls. The cross-sections allow us to follow the hypothesized relationship over time and the panel element allows us to remove time invariant unobserved establishment heterogeneity.

Managers provide information about the share of employees formally cross-trained. The specific question asks "Approximately, what proportion of employees in the largest nonmanagerial occupational group are formally trained to be able to do jobs other than their own?" (COTHJOB) The question asks explicitly about cross-training (training to do the task of another) which, as we indicated, has been closely tied to reduced costs and specific skills. Moreover, as it identifies formal training, it seems likely to be employer provided. It clearly is not identifying mere helping effort on the job or learning by doing. Nonetheless, we recognize that the question does not identify whether or not training takes place on site or whether workers receive time off for it. Thus, we supplement it with two alternative training 
measures that ask "What proportion of experienced people in the largest non-managerial occupational group have been given time from their normal daily duties to undertake training over the past 12 months" (COFFJOB) and if such training was received, "On average how many days of training did experienced employees undertake over the past 12 months." (CTRAIN) These are broader measures that likely consist of portions of both general and specific training. By examining both our preferred cross-training variable and these two supplemental training measures a more complete picture can be presented.

Managers provide one of seven answers to the cross-training question: None (0\%), Just a few (1-19\%), Some (20-39\%), Around half (40-59\%), Most (60-79\%), Almost all (8099\%) and All (100\%). Appendix Table A1 provides the distribution of responses and suggests a reasonably stable pattern over time. Approximately, 1 out of 3 managers answered that 'None' of the employees were formally trained to do jobs other than their own, about 1 out of 4 managers said 'Just a few: 1-19\%' and about 1 out of 10 managers said 'All'. Responses to the other two training questions are also categorical responses that reflect ordered bands.

Managers identify the number of competitors they face by responding to the following question: "If trading sector and trading externally", how many competitors do you have for your (main) product or service? (Prompt: ‘few' equal 5 or less)” to which managers could respond 1. 'None/Organisation dominates market'; 2. 'Few competitors' or 3. 'Many competitors'. This question does not provide a quantitative measure such as a concentration index but does allow the manager to identify the product and geographic market in which they compete. This can be critical as managers seem likely to include relevant competitors even when they are outside the standard industry or geographic boundaries of the official

\footnotetext{
${ }^{4}$ Establishments trading externally provide goods and services to the general public and/or to other organizations rather than exclusively supplying other parts of their own organization.
} 
index. ${ }^{5}$ As a robustness check, we also use the objective measure of industrial concentration associated with each establishment's three-digit industrial code. Specifically, we use a concentration index generated by the Office of National Statistics. The index measures the percentage of the market value of industry output produced by the top five firms within the industry. $^{6}$ While such a concentration index poorly captures product differentiation, import penetration or firm-specific factors, it has the advantage of not varying with each manager's potentially subjective judgement. This alternative measure returns qualitatively similar results.

Appendix Table A2 provides the distribution of responses by managers and again shows reasonable stability. In all three cross sections about sixty percent of the managers said that they had many competitors, between thirty and forty percent said that they had less than five competitors, and between two and six percent said that their product or service dominated the market.

In examining the relationship between market structure and competition we will control for an extensive set of covariates. We describe this process in the next subsection but emphasize that the descriptive statistics for the two alternative measures of training, for all the covariates (for WERS 2011) and for the concentration indices are in Tables I, II, III and IV respectively of the supplementary online appendix.

\subsection{Empirical methodology}

The initial empirical objective is to estimate ordered probits in which the categorical measures of the extent of training for all three measures are a function of the extent of competition and suitable controls. We begin with cross-sectional estimates for each of the

\footnotetext{
${ }^{5}$ Emphasizing this point is not unique to us and the number of self-identified competitors has been used by Blanchflower and Machin (1996) and Bloom et al. (2010) among others.

${ }^{6}$ In unreported estimates we use the equivalent measure for value added rather than output. The main estimates of interest are essentially unchanged with this alternative measure.
} 
three years. In a baseline estimate we recognize that many potential controls could be endogenous as they may be influenced by the extent of training. As a consequence, we start with a fairly parsimonious specification and later show that the critical results are little changed by substantially increasing the number and variety of control variables. The parsimonious specification includes controls for industry, region and occupational composition (Brunello and De Paola 2008) as well as basic workforce descriptions including the gender and age structure and indicators of separations and quits (Altonji and Spletzer 1991). Finally, recognizing that cross-training might substitute for the use of temporary agency and fixed term employees when providing short-term cover for absent workers (Inman et al. 2005), we control for the use of fixed term, agency and part-time workers. We show that in each cross-section and for all three measures of training those establishments holding a more dominant product market position engage in more training. ${ }^{7}$

After examining the magnitude of the relationship between cross-training and dominance, we expand our controls recognizing their possible endogeneity. Vives (2008) makes clear that market structure influences workplace innovation and so may, itself, influence some of the controls as well as the extent of training. Thus, the stability of the estimates is important as it suggests that endogeneity is not likely to drive our results. We find that as we increase the number of controls, the magnitude of the critical market structure result does not substantially vary.

In adding controls, there may be substantial fixed costs in establishing a formal training program, and large establishments can spread out these costs across many workers (Black et al. 1999). Moreover, more complex operations may require greater training. Thus, we control for log number of employees, the number of years the establishment has been in operation (in logs), if the establishment produces multiple products or services, and whether

\footnotetext{
${ }^{7}$ It might be argued that even the controls in the parsimonious specification could be endogenous; yet the fundamental statistical correlations remain when the critical competition measures are the only independent variables.
} 
the establishment is part of a larger organization (multi-establishment). The presence of trade unions has been shown to be associated with training (Boheim and Booth 2004) causing us to also control for the percentage of the workforce in a union.

In a further estimate we retain all these just added controls and also add indicators of human resource management practices including whether or not the establishment conducts personality/attitude and performance/competency tests when filling vacancies, the presence of quality circles, the presence of joint consultative committees, and whether or not there is a just-in-time inventory system. In the end, we recognize that bundles of human resource management practices may come together for strategic reasons and want to control for as many as we can in an effort to isolate the influence of product market position. The basic notion is that training is seen as a critical part of a bundle of high performance workplace practices (Whitfield 2000). A final estimate adds indicators of performance-related pay to all of the previous controls. These variables capture whether or not employees are paid by results, receive merit pay, receive profit related payments or bonuses, or can purchase company shares. Such reward structures are often associated with reduced managerial supervision, reduced chance of layoff and increased training (Kraft and Lang 2013). While some of these new controls emerge as significant, there is little indication that they are critical omitted variables, as the magnitude of the market structure estimates remains relatively stable. This stability in the face of large changes in the control vector also helps provide reassurance that endogenous included controls are not driving our results.

We then move on to the two panels. Here we experiment with several specifications but the concern is that unmeasured but time-invariant heterogeneity influences both market position and the extent of cross-training. Thus, we hold constant time invariant characteristics of the establishment and still show that increases in market dominance are reflected in greater cross-training. 
We next experiment with our alternative measure of market concentration, the official industry level concentration ratio reported by the ONS. The pooled and fixed effect estimates continue to be supportive. We then return to our original market structure measures and use an aggregation strategy to develop sensible IV estimators. Following Fisman and Svensson (2007) and Lai and Ng (2014) we imagine that a given firm's training decisions are not determined by the average degree of market dominance of other establishments in the industry but that this average is highly correlated with its own degree of market dominance. We estimate IV models for all three cross-sections and both panels. We concentrate on a variant of the panel IV estimates that also hold constant time invariant fixed establishment effects. The diagnostics are supportive and market dominance remains associated with greater training. As we move through the empirical results, we summarize further robustness exercises but often relegate them to the on-line appendix.

\section{Empirical Results}

The first column of Table 1 presents the baseline ordered probit estimate of the extent of cross-training using the most recent 2011 cross section. The dependent variable is the extent of cross-training. Our inclusion of industry dummies should hold constant industry fixed effects and the remaining variation in the dependent variable should come from establishments within an industry. ${ }^{8}$ The results show that higher percentages of female and fixed term workers are associated with greater training while higher percentages of employees older than 50 and higher quit rates are associated with reduced training (see Dearden et al. 1997; Booth and Zoega 1999; Munasinghe and O’Flaherty 2005). Critically, establishments in the two more competitive market structures do significantly less crosstraining when compared to those that dominate their market.

\footnotetext{
${ }^{8}$ Removing the industry dummies does not change the role for market dominance in the estimations.
} 


\section{INSERT TABLE 1}

Column 2 reports estimates from an identical model in which the dependent variable is the proportion of workers given time off for training in the last year. The results confirm expectations with the two more competitive market structures again doing significantly less training of their workforce by this measure. This is reinforced further in column 3. The results indicate that establishments in the two more competitive market structures also provide fewer days of training when they do provide it. Thus, the measures of both breadth and depth of training, as well as the specific measure of cross-training, all suggest dominant firms provide more training.

We have repeated the same series of three estimates using the 1998 and the 2004 cross-sections. The critical results on market competition indicate not only that the 2011 estimate is robust across training measures but that this holds for earlier years. The critical coefficients for the number of competitors remain negative and statistically significant confirming that dominant firms engage in more training as measured by all three training indicators in all three years. The results for 1998 and 2004 are reported in Table V in the online appendix and closely mimic those shown in Table 1.

Importantly, both those firms with a few competitors and those with many competitors engage in less cross-training than do firms dominant in their market. These former two coefficients are not statistically significantly different from each other, but together with the cut-off points can be used to estimate the marginal influence relative to those establishments that are dominant. A full set of marginal effects for all three crosssections is reported in Table VI in the on-line appendix but we note that those for 2011 were the largest with, for example, the marginal effect of moving from a dominant firm to one with a few competitors associated with an increase of 0.196 in the probability of cross training none of the workforce and a reduction of 0.093 in the probability of cross training all of the 
workforce. Thus, the marginal effects in the tails of the cross-training distribution are substantial and appear to be increasingly sensitive over time to the presence of dominant firms.

We now add additional controls to our parsimonious estimation in order to demonstrate the stability of our estimates. These controls may, themselves, be endogenous, and so the stability of the estimates is important as it suggests that such endogeneity is not driving our results. Thus, Column 1 of Table 2 reproduces our original cross-sectional estimates. Column 2 adds the vector of additional establishment and workforce characteristics, while Column 3 adds measures of human resource management strategy and practice. These additional controls do not change the estimated impact of market structure. Column 4 adds measures of performance pay which appear important with three of the four measures associated with greater training. If anything, adding these measures causes the estimated importance of a dominant position to appear slightly greater. Yet, the overarching point is that in all these robustness checks, dominant firms engage in significantly more cross-training.

\section{INSERT TABLE 2}

\subsection{Panel Estimates}

Table 3 moves to the panel data where we now observe establishments in two adjoining survey waves. In the fixed effect estimates the establishments that change their degree of competition category identify the influence of market structure on training. ${ }^{9}$ We start by presenting a pooled estimate without establishment fixed effects on the panel samples of

\footnotetext{
${ }^{9}$ There are 424 observations associated with a change competition category between 1998 and 2004 and 340 establishments associated with a change competition category between 2004 and 2011.
} 
establishments. These results are in Columns 1 (1998-2004) and 5 (2004-2011) and reveal the familiar pattern that establishments with a dominant position engage in more crosstraining. The point estimates of the two competition variables in the two panel samples are roughly comparable to earlier cross-section estimates suggesting that those in the panel are not an unusually selected sample. As an example, the 2004-2011 marginal effects indicate that an establishment with a few competitors has an increased probability of training no workers of 0.113 and a reduced probability of training all workers of 0.038 . The full set of marginal effects is available upon request.

\section{INSERT TABLE 3}

Columns 2 and 6 present the results from an OLS estimate which simply treats the ordered categories of training as cardinal by taking the mid-points of the ranges in the underlying categories. While we could directly move to a fully comparable fixed-effect ordered probit estimate, it necessarily suffers from the incidental parameter problem associated with many nonlinear estimates (see Greene 2001). Instead, we estimate the pooled OLS to demonstrate that they suggest very similar results. The two market structure indicators follow the anticipated ordering in size but are not statistically different from each other. Both remain statistically significant and the magnitude suggests that dominant firms engage in 0.3 of a category more training.

The OLS model allows holding constant time invariant characteristics that might influence both the extent of cross-training and the market position of the firm without the incidental parameter problem. Columns 3 and 7 present the fixed effect estimates for the two panels. They emerge as larger (more negative) than those in the pooled estimates on exactly the same sample. Thus, to the extent that unmeasured time invariant characteristics influence the cross-section estimates, they seem to generate a downward bias. The estimates suggest 
that the influence of dominant firm grows to around 0.45 of a category when accounting for fixed effects.

The role for market structure remains robust when limiting the sample to only those establishments in which the market structure category changes (the movers) and re-estimating the extent of training as a pooled cross-section of the two years. The coefficients again mimic those in the pooled panel and in the individual waves at about two-thirds the size of the fixed effect estimates. This shows the importance of the fixed effects and also suggests that the sample of movers is not a highly selected sample.

As further robustness tests, we tried several functional forms for our fixed effect estimate. We recognize that our cardinal ranking can be viewed as essentially a count variable. This allows estimation of the fixed-effect Poisson regression, one of the few nonlinear fixed effect estimators without incidental parameter concerns (Hilbe and Greene 2008). The results from this exercise are presented in columns 4 and 8. The estimated coefficients maintain the signs and statistical significance we have shown throughout and magnitudes suggest they are broadly similar to those associated with the OLS. We also estimated conditional fixed effect logits (which eliminate the incidental parameter problem) by dividing the categories of training into high and low and, as well as fixed effect ordered probits (available as a canned routine in LIMDEP) that retain the incidental parameter problem. These are available upon request and simply confirm the patterns of the two fixed effect estimates we show in Table 3.

Table 4 estimates the fixed effect specifications using the other two measures of training as the dependent variables. For both measures the two more competitive market structures emerge with negative and significant coefficients (at least at the 10 percent level). Again, the fixed effect Poisson also returns significant coefficients and is available upon request. While the days of training question is simply not asked in the first panel, it is 
reassuring that essentially the same pattern of negative coefficients emerges in both panels, under alternative fixed-effect specifications and across three measures of training. At minimum, we find no indication that the cross-sectional finding that dominant firms engage in more training is the result of invariant establishment specific effects. Instead, the crosssectional estimates appear to diminish the larger role actually played by dominant market position.

\section{INSERT TABLE 4}

As a further robustness check, we replace our measure of market dominance with the concentration index. While this industry output share of the five largest firms may not accurately identify the market in terms of product and geography (Mahajan 2006), it has the advantage of not being a potentially subjective and misleading view of the manager. Table 5 shows that the concentration index takes a positive and highly significant coefficient indicating that the more concentrated the industry the greater is the provision of training. This emerges in both the 2004 and 2011 cross-sections. More importantly, the third column indicates that when holding constant establishment level fixed effects, an increase in industry concentration is associated with an increase in the extent of training. Thus, the pattern of results confirms that found with the subjective measure of the number of competitors provided by the managers. Full estimates and associated marginal effects are available from the authors but the agreement of the two market structure measures is reassuring. ${ }^{10}$

\section{INSERT TABLE 5}

\footnotetext{
${ }^{10}$ We also estimate the fixed effect specification with an alternative ratio of the value added of the five largest firms in the industry. It behaves very similarly returning a positive and significant coefficient. Moreover, the concentration measures (whether output or value-added) can be expressed in logs and still return significant positive coefficients. All of these alternative estimates are available upon request.
} 


\subsection{Further issues of Endogeneity}

We recognize that the correlation between market structure and the extent of training could emerge only because they each reflect the same exogenous determinants. In this view, endogeneity leaves suspect the estimates that we report and while the fixed effect estimates are reassuring, they do not settle the matter. As an illustration, superior management might both invest more in training and generate a dominant market position. More dramatically, the causation could be reversed as the investments in training create a competitive advantage which eventually results in market dominance. To examine this we undertake several related IV estimates that also control for establishment fixed effects. These estimates are supportive of an independent role of market dominance.

We concentrate on the panel estimates and again contrast an estimate that does not hold constant establishment fixed effects with one that does hold them constant. We adopt an instrumental variable strategy based on industrial aggregation [for examples see Fisman and Svensson (2007); Lai and Ng (2014)]. The strategy posits that there are characteristics of the product and its industry that help define the extent of competition between firms within that industry. In our case, product and industry characteristics stand as exogenous influences that make it more or less likely that firms within the industry will find they have few or many competitors (as opposed to a dominant position). The empirical implementation generates identifying variables that aggregate the indicators for few or many competitors. The aggregates (averaged to the proportion in each competition category) vary by establishment in the industry by excluding the establishment for which it is computed. Thus, the identifying variables are the proportions in each category for other establishments in a given establishment's industry.

Table 6 summarizes the first of these estimates. Here we examine the early panel (1998-2004). We initially pool the data and instrument. There are two endogenous dummy 
indicators, a few and many competitors. Using two stage least squares, linear probability models are estimated in the first stages for the endogenous indicators with the cardinal value of the training value as ultimate second stage dependent variable. The first stages regresses each establishment's value of the competition indicator (zero or one) against all the joint variables and both aggregated industry proportions for the competition indicators (Baltagi 2011 p. 245). The second stage returns the two estimated values from the first stage along with the joint variables to the estimates on training and clusters the standard errors at workplace cells. The results demonstrate that the first stage routinely shows a strong positive correlation between the industry average and the excluded establishment value. Moreover, there is no evidence of weak instruments and the other diagnostics are also supportive. The second stage shows the familiar increasing coefficients with both significantly different from zero and of broadly similar size.

\section{INSERT TABLE 6}

Columns 4 to 6 combine the instrumental variable strategy with a fixed effect estimate. We alter the procedure slightly from the pooled estimates by now clustering errors at industry cells as each pair of firms now contribute at most once to the fixed effect estimate. The coefficients from the fixed effect estimate follow the earlier pattern and continue to be larger. The diagnostics continue to be supportive. Importantly, it continues to be evident that establishments with few or many competitors engage in more training. As is often the case in applied work, the IV estimates tend to be larger than those without instrumenting. This may reflect that instrumenting has reduced measurement error and the associated attenuation bias or it may reflect a genuinely larger local average treatment effect. Importantly, there is no evidence that the earlier estimates without instrumenting were biased upward. 
Table 7 reproduces the pooled and fixed effect estimates for the $2004-2011$ panel. The pattern of results strongly persists in the second panel. The first stage estimates continue to show a strong role for the industry averages. The diagnostics continue to be supportive and the ultimate role of the predicted values continues to demonstrate that establishments with more competitors do less training. The ordering of the two coefficients remains and they exhibit high statistical significance in both the pooled and fixed effect estimates. Again, the fixed effect estimates remain larger as they have throughout. ${ }^{11}$

\section{INSERT TABLE 7}

As indicated, these estimates do not close the book on the interplay of possible causations but they do suggest that plausibly independent movements in market structure are associated with the extent of training. When the IV is combined with the fixed effect estimates, they add confidence to our results and seem sensible. Innovation, product market advantages and unique assets seem more likely to generate market dominance than training which would seem more easily replicated by all firms in the market. Thus, if training (or cross-training in particular) was such a strong competitive weapon, one would anticipate that all firms would engage in it. If they all engage in it, one should observe extensive crosstraining even in cases without dominance which is not the case in our evidence.

\section{Conclusion}

Training represents an investment in an establishment's workforce that provides a return by making workers more productive and so lowering the cost of production. We emphasize in our formal model that rent effects imply that the incentive for such investment

\footnotetext{
${ }^{11}$ We also returned to the industrial concentration measure and implemented an IV strategy for the fixed effect estimates presented in Table 7. We used the lagged value of concentration as an instrument for the current value. While the results remain highly supportive and are presented in Table VII of the on-line appendix, we recognize that persistence in the dependent variable may undermine the reliability of this strategy (Reed 2015). We appreciate an anonymous referee for making this limitation clear.
} 
can be larger for more monopolistic firms. This motivated our empirical investigation and we focus our conclusion on what has been learned by that investigation.

Using British establishment data from three cross-sections, we found dominant establishments train a substantially larger share of their workforce and train them longer. This remains true throughout a large variety of specifications and across three training measures. We focused on cross-training as it seems likely to be firm-provided and to contain a large share of firm-specific skills. The estimated role of market dominance remained remarkably stable in the face of large changes in the vector of controls.

When we moved to two separate panels, we confirmed the role of market dominance even when controlling for time invariant fixed effects. This was true for all three measures of training and across a variety of fixed-effect specifications. We examined a series of measures of market structure that return qualitatively similar results. It does not appear to matter whether one uses the subjective measure of the manager or objective official measures. They each show a role in the fixed effect estimates. We also undertook instrumental variables estimates which continued to suggest a role for market dominance. While not the final word on causation, they remain supportive of the hypothesis that dominant firms do more training. Critically, the combination of the IV and controlling for establishment fixed effects provides evidence that independent variation in market dominance influences training.

We raise several caveats in closing. First, we certainly have not shown or suggested that dominant market structures are welfare superior. Even as dominant firms undertake additional training, they may be associated with more than offsetting distortions in the product market as they raise prices relative to more competitive market structures. We have simply shown evidence supporting the hypothesis that part of any overall evaluation should be the greater training associated with dominance. Second, product market structure itself may determine whether a given skill is general or specific. Thus, all skills unique to an 
industry are general in a competitive market and completely specific in a monopoly. If specific skills are provided by the firm, we should anticipate the extent of firm-provided skills to be greater in a monopoly. We have no easy way to distinguish this from the scale effect we model but emphasize that it would move in the same direction. In the end, it remains a valuable contribution to have demonstrated that one of the most familiar models of competition can predict larger investments in training by more monopolistic firms and to follow this with robust evidence that dominant establishments in Britain provide more training. 


\section{References}

Abramovsky, L. Battistin, E., Fitzsimons, E., Goodman, A. and Simpson, H. (2011).

'Providing Employers with Incentives to Train Low-Skilled Workers: Evidence from the UK Employer Training Pilots’ Journal of Labor Economics 29, 153-193.

Acemoglu, D. (1997). 'Training and Innovation in an Imperfect Labor Market' Review of Economic Studies 64, 445-464.

Acemoglu, D. and Pischke, J. S. (1998). 'Why Do Firms Train? Theory and Evidence' Quarterly Journal of Economics 113, 79-119.

Acemoglu, D. and Pischke, J. S. (1999). 'The Structure of Wages and Investment in General Training’ Journal of Political Economy 107, 539-572.

Altonji, J.G. and Spletzer, J.R. (1991). 'Worker Characteristics, Job Characteristics, and the Receipt of On-the-Job Training’ Industrial and Labor Relations Review 45, 58-79.

Aghion, P., Bloom, N., Blundell, R., Griffith, R. andHowitt, P. (2005). 'Competition and Innovation: an Inverted-U Relationship’ Quarterly Journal of Economics 120, 701 - 728.

Arulampalam, W., Booth, A.L and Bryan, M.L. (2004). 'Training in Europe' Journal of the European Economic Association, 2(2-3), 346-360.

Autor, David, H. (2001). 'Why Do Temporary Help Firms Provide Free General Skills Training?’ Quarterly Journal of Economics 116, 1409-1448.

Baltagi, B. H. (2011). Econometrics. New York: Springer.

Barron, J.M., Berger, M.C. and Black, D.A. (1997). 'How Well Do We Measure Training' Journal of Labor Economics 15, 507-528.

Bassanini, A. and Brunello, G. (2011). 'Barriers to Entry, Deregulation and Workplace Training’ European Economic Review 55, 1152-1176.

Bassanini, A., Booth, A., Brunello, G., De Paola, M., and Leuven, E. (2007). Workplace Training in Europe in G. Brunello, P. Garibaldi, and E. Wasmer (eds.), Education and Training in Europe, Oxford University Press, Oxford UK.

Becker, G. (1964). Human capital (2nd edition). Columbia University Press.

Black, D.A, Noel, B.J. and Wang, Z. (1999). 'On-the-Job Training Establishment Size, and Firm Size: Evidence for Economies of Scale in the Production of Human Capital' Southern Economic Journal 66, 82 - 100.

Blanchflower, D. and Machin, S. (1996). 'Product Market Competition, Wages and Productivity: International Evidence from Establishment Data', Annals of Economics and Statistics/Annales D'Economie et de Statistique, No. 41/42, pp. 219-253. 
Bloom, B., Sadun, R. and Van Reenen, J. (2010). 'Does Product Market Competition Lead Firms to Decentralize?’ American Economic Review, Papers and Proceedings, 100, pp. 434438.

Blundell, R., Dearden, L., Meghir, C. and Sianesi, B. (1999). 'Human Capital Investment: The Returns from Education and Training to the Individual, the Firm and the Economy' Fiscal Studies 20, 1-23.

Boeri, T and van Ours, J. (2013). The Economics of Imperfect Labor Markets, Second Edition, Princeton University Press, Princeton and Oxford.

Boheim, R. and Booth, A. (2004). 'Trade Union Presence and Employer Provided Training in Great Britain’ Industrial Relations 43, 520 - 545.

Booth, A. and Bryan, M. (2005). 'Testing Some Predictions of Human Capital Theory: New Training Evidence from Britain’ Review of Economics and Statistics 87, 391- 394.

Booth, A. and Snower, D. (1996). Acquiring Skills: Market Failures, their Symptoms and Policy Responses, Cambridge University Press.

Booth, A. and Zoega, G. (1999). 'Do Quits Cause Under-Training' Oxford Economic Papers 51, 374-386.

Brunello, G. and Gambarotto, F. (2007). 'Do Spatial Agglomeration and Local Labor Market Competition Affect Employer-Provided Training? Evidence from the UK' Regional Science and Urban Economics 37, 1 - 21.

Brunello, G. and De Paola M. (2008). 'Training and Economic Density: Some Evidence form Italian Provinces’ Labour Economics 15, 118-140.

Cappelli, P. and Rogovsky, N. (1994). 'New Work Systems and Skill Requirements' International Labor Review 133, 205 - 220.

Carmichael, H.L and MacLeod, B. (1993). 'Multi-Skilling, Technical Change and the Japanese Firm’ Economic Journal 103, 142 - 160.

Chaplin, J., Mangla, J., Purdon, S. and Airey, C. (2005). 'The Workplace Employment Relations Survey 2004 (WERS 2004) Technical Report (Cross Section and Panel Surveys)', London: National Centre for Social Research.

Dearden, L., Machin, S. Reed, F. and Wilkinson, D. (1997). Labour Turnover and Work Related Training. London: Institute for Fiscal Studies Report (R53).

DOI:10.1920/re.ifs.1997.0053.

Dearden, L., Reed, H. and van Reenen, J. (2006). 'The Impact of Training on Productivity and Wages: Evidence from British Panel Data' Oxford Bulletin of Economics and Statistics 68, 397-421.

Finegold, D. and Soskice, D. (1988). 'The Failure of Training in Britain: Analysis and Prescription' Oxford Review of Economic Policy 4, 21-53. 
Fisman, R. and Svensson, J. (2007). 'Are Corruption and Taxation Really Harmful to Growth? Firm Level Evidence’ Journal of Development Economics 83, pp. 63-75.

Gersbach, H and Schmutzler, A. (2012). 'Product Market and Industry-Specific Training' Rand Journal of Economics 43, 475-491.

Görlitz, K. and Stiebale, J. (2011). 'The Impact of Product Market Competition on Employers' Training Investments. Evidence from German Establishment Panel Data’ De Economist 159, 1-23.

Greene, W. H. (2001). 'Estimating Econometric Models with Fixed Effects' Discussion Paper, Department of Economics, Stern School of Business, New York University.

Heywood, J., Jirjahn, U. and X. Wei. (2008). 'Teamwork, Monitoring and Absence' Journal of Economic Behavior and Organization 68, 676 - 690.

Hilbe, J.M. and Greene, W.H. (2008). Count Regression Models, Chapter 7 in Handbook of Statistics (Epidemiology and Medical Statistics) Vol. 27, 210-252, edited by C.R. Rao, J.P. Miller and D.C. Rao.

Hopp, W.J, Tekin, E. and Van Oyen, M.P. (2004). 'Benefits of Skill Chaining in Serial Production Lines with Cross-Trained Workers’ Management Science 50, 83-98.

Inman, R.R., D.E. Blumenfield and A. Ko. (2005). 'Cross-Training Hospital Nurses to Reduce Staffing Costs’ Health Care Management Review 30, 116 - 125.

Jones, D.C., Kalmi, P. and Kauhanen, A. (2012). 'The Effects of General and Firm-Specific Training on Wages and Performance: Evidence from Banking' Oxford Economic Papers 151, 151-175.

Katz, E. and Ziderman, A. (1990). 'Investment in General Training: The Role of Information and Labour Mobility’ Economic Journal 100, 1147-1158.

Konings, J. and Vanormelingen, S. (2015). 'The Impact of Training on Productivity and Wages: Firm-Level Evidence’ Review of Economics and Statistics 97, 485-497.

Kraft, K. and Lang, J. (2013). 'Profit Sharing and Training' Oxford Bulletin of Economics and Statistics 75, 940-961.

Krueger, A. B. (1993). 'How Computers Have Changed the Wage Structure: Evidence from Micro Data, 1984-1989’ Quarterly Journal of Economics 108, 33-60.

Lai, Tat-Kei. and Ng, T. (2014). 'The Impact of Product Market Competition on Training Provision: Evidence from Canada’ Canadian Journal of Economics 47, 856-888.

Lazear, E.P. (2009). 'Firm-Specific Human Capital: A Skill-Weights Approach’ Journal of Political Economy 117, 914-940. 
Lynch, M.L. (1994). Training and the Private Sector: International Comparisons. The University of Chicago Press. Chicago and London. Edited by Lisa M. Lynch (NBER comparative labor market series).

Mahajan, S. (2006). 'Concentration Ratios for Business by Industry in 2004' Economic Trends October 2006, 25 - 47, Office of National Statistics, UK government, London.

Manning, A. (2003). Monopsony in Motion: Imperfect Competition in Labor Markets, Princeton University Press, Princeton and Oxford.

Moretti, E. (2004). 'Worker's Education, Spillovers and Productivity: Evidence from Plant Level Production Functions’ American Economic Review 94, 656-690.

Morita, H. (2005). 'Multi-Skilling, Delegation and Continuous Process Improvement: A Comparative Analysis of US-Japanese Work Organizations’ Economica 72, 69-93.

Munasinghe, L. and O’Flaherty, B. (2005). ‘Specific Training Sometimes Cuts Wages and Always Cuts Turnover’ Journal of Labor Economics 23, 213-233.

Picchio, M. and van Ours, J. (2011). 'Market Imperfections and Firm-Sponsored Training' Labour Economics 18, 712-722.

Reed, W. R. (2015). 'On the Practice of Lagging Variables to Avoid Simultaneity' Oxford Bulletin of Economics and Statistics 77, 897 - 905.

Slomp, J. and Molleman, E. (2002). 'Cross-Training Policies and Team Effectiveness' International Journal of Production Research 40, 1193-2019.

Stevens, M. (1994). 'A Theoretical Model of on-the-Job Training with Imperfect Competition’ Oxford Economic Papers 46, 537-562.

Van Wanrooy, B., Bewley, H., Bryson, A., Forth, J., Freeth, S., Stokes, L., and Wood, S. (2013). The 2011 Workplace Employment Relations Survey: First Findings. Available from: https://www.gov.uk/government/uploads/system/uploads/attachment_data/file/210103/13-1010-WERS-firstfindings-report-third-edition-may-2013.pdf

Varian, H. R. (1992). Microeconomic Analysis. W.W. Norton and Company.

Vives, X. (2008). 'Innovation and Competitive Pressure' Journal of Industrial Economics 56, 419-469.

Whitfield, K. (2000). 'High-Performance Workplaces, Training, and the Distribution of Skills’ Industrial Relations 39, 1-25.

Wolter, S.C. and Ryan, P. (2011). Apprenticeship. Chapter 11, pp. 521-576 in Handbook of the Economics of Education, Vol. 3 edited by, Hanushek, E., Machin, S., and Woessmann, L. North-Holland, Elsiever.

Zwick, T. (2006). 'The Impact of Training Intensity on Establishment Productivity' Industrial Relations 45, 26-46. 


\section{Appendix}

Suppose the price of the good is given by the inverse demand function $p(q)=a-q$, where $a>0$. The cost of training for firm $j$ is given by the convex function $h\left(I_{j} ; q_{j}\right)=\theta I_{j}^{2} / 2+\gamma I_{j} q_{j}$, where $\theta, \gamma>0$. The cost of training is not assumed to be a fixed cost but to increase with output (i.e. with the level of employment). ${ }^{12}$ In particular, the parameter $\gamma$ represents the additional cost of training one more percentage point of the workforce when the firm produces one more unit of output: $\partial^{2} h / \partial I_{j} \partial q_{j}=\gamma>0$. Training improves worker productivity and thus reduces the marginal cost of production. We capture this in the simple unit cost function $\varphi\left(q_{j} ; I_{j}\right)=c_{j} q_{j}=c\left(1-I_{j}\right) q_{j}$ which implies the marginal cost of production $c\left(1-I_{j}\right)$ decreases with training. Thus, firm $j$ 's overall cost function is:

$$
h\left(I_{j} ; q_{j}\right)+\varphi\left(q_{j} ; I_{j}\right)=\left[c-(c-\gamma) I_{j}\right] q_{j}+\theta I_{j}^{2} / 2=C\left(q_{j}, I_{j}\right)+g\left(I_{j}\right) \text {, where } \gamma<c<a
$$

With this formulation, the second-stage Cournot-Nash equilibrium outcome involves:

$$
\left(q_{j}^{C}, p^{C}\right)=\left(\frac{a-c+(c-\gamma) \cdot\left(n I_{j}-\sum_{i \neq j} I_{i}\right)}{n+1}, \frac{a+n c-(c-\gamma) \cdot \sum_{i=1}^{n} I_{i}}{n+1}\right)
$$

We can also compute firm j's second-stage profit:

$$
\Pi_{j}^{C}\left(I_{j}, I_{-j}\right)=\left(q_{j}^{C}\right)^{2}-\theta I_{j}^{2} / 2
$$

In stage 1, the profit-maximization problem for each firm $j$ is $\max _{\left\{I_{j}\right\}} \Pi_{j}^{C}\left(I_{j}, I_{-j}\right)$ s.t. $0 \leq I_{j} \leq 1$.

The solution of the associated Kuhn-Tucker first-order conditions (after imposing the symmetry condition $I_{i}=I_{j}$ for all $\left.i, j=1, \ldots, n\right)$ implies the equilibrium level of training investment described below:

\footnotetext{
${ }^{12}$ In the special case where $\gamma=0$, the cost of training is a fixed cost for the employer as in Bassanini and Brunello (2011).
} 
(i) For $\theta \leq k / 2$ :

$$
I_{j}^{*}=\left\{\begin{array}{cl}
1 & , \text { if } 1 \leq n \leq \frac{(k-\theta)+\sqrt{k(k-2 \theta)}}{\theta} \\
\frac{2 n k}{\theta(n+1)^{2}-2 n(c-\gamma)^{2}} \in(0,1) & , \text { if } \frac{(k-\theta)+\sqrt{k(k-2 \theta)}}{\theta} \leq n<\infty \\
0 & , \text { if } n \rightarrow \infty
\end{array}\right.
$$

where $k \equiv(c-\gamma)(a-\gamma)$

(ii) For $\theta \geq k / 2$ :

$$
I_{j}^{*}=\left\{\begin{array}{cl}
\frac{2 n k}{\theta(n+1)^{2}-2 n(c-\gamma)^{2}} \in(0,1) & , \text { if } 1 \leq n<\infty \\
0 & \text {, if } n \rightarrow \infty
\end{array}\right.
$$

Case (i) reveals that the firm might be willing to train all its employees $\left(I_{j}^{*}=1\right)$ provided the marginal cost of training $(\theta)$ is low and there is a relatively small number of firms in the market. On the contrary, if the cost of training is high enough the proportion of trained workers will be lower than one regardless of the number of competitors. Finally, the other boundary case where the firm does not provide training at all $\left(I_{j}^{*}=0\right)$ can be reached when the market tends to be perfectly competitive (i.e. for $n \rightarrow \infty$ ).

It can be seen that the interior solution decreases with the number of firms:

$$
\frac{\partial I_{j}^{*}}{\partial n}=\frac{2 k \theta\left(1-n^{2}\right)}{\left[\theta(n+1)^{2}-2 n(c-\gamma)^{2}\right]^{2}}<0 \text { for all } n>1
$$

As a result, the effect of product market competition on the equilibrium level of training is fully described in the following proposition.

Proposition A1. Increasing product market competition, $n$, reduces training: $\partial I_{j}^{*} / \partial n \leq 0$ for all $n>1$

In order to get a fuller understanding of this result, we write down the marginal profit expression: 


$$
\frac{\partial \Pi_{j}^{C}}{\partial I_{j}}=2 q_{j}^{C} \cdot \frac{\partial q_{j}^{C}}{\partial I_{j}}-\theta I_{j}=2 \cdot \frac{a-c+n(c-\gamma) I_{j}-(c-\gamma) \cdot \sum_{i \neq j} I_{i}}{n+1} \cdot \frac{n(c-\gamma)}{n+1}-\theta I_{j}
$$

Under symmetry ( $I_{i}=I_{j}$ for all $i, j=1, \ldots, n$ ), the Cournot equilibrium quantities and price become:

$$
\left(q_{j}^{C S}, p^{C S}\right)=\left(\frac{a-c+(c-\gamma) I_{j}}{n+1}, \frac{a+n c-n(c-\gamma) I_{j}}{n+1}\right)
$$

Then, equation (A7) takes the following form:

$$
\frac{\partial \Pi_{j}^{C}}{\partial I_{j}}=2 q_{j}^{C S} \cdot \frac{\partial q_{j}^{C}}{\partial I_{j}}-\theta I_{j}=2 \cdot \frac{a-c+(c-\gamma) I_{j}}{n+1} \cdot \frac{n(c-\gamma)}{n+1}-\theta I_{j}
$$

Partial differentiation of the last expression finally yields:

$$
\begin{aligned}
& \frac{\partial^{2} \Pi_{j}^{C}}{\partial I_{j} \partial n}=2 \cdot\left[\frac{\partial q_{j}^{C S}}{\partial n} \cdot \frac{\partial q_{j}^{C}}{\partial I_{j}}+q_{j}^{C S} \cdot \frac{\partial^{2} q_{j}^{C}}{\partial I_{j} \partial n}\right]=2 \cdot\left[-\frac{a-c+(c-\gamma) I_{j}^{*}}{(n+1)^{2}} \cdot \frac{n(c-\gamma)}{n+1}+\frac{a-c+(c-\gamma) I_{j}^{*}}{n+1} \cdot \frac{c-\gamma}{(n+1)^{2}}\right]= \\
& =\frac{2(c-\gamma)\left[a-c+(c-\gamma) I_{j}^{*}\right](1-n)}{(n+1)^{3}}<0 \text { for all } n>1
\end{aligned}
$$

as stated in the main text. Therefore, the sign of the derivative $\partial I_{j}^{*} / \partial n$ will also be negative in this case. 
Table 1. Training and Product Market Competition: WERS 2011

\begin{tabular}{|c|c|c|c|}
\hline & $\begin{array}{c}(1) \\
\text { COTHJOB }\end{array}$ & $\begin{array}{c}(2) \\
\text { COFFJOB }\end{array}$ & $\begin{array}{c}(3) \\
\text { CTRAIN }\end{array}$ \\
\hline Few competitors & $\begin{array}{c}-0.579 * * * \\
(0.213)\end{array}$ & $\begin{array}{c}-0.459 * * \\
(0.194)\end{array}$ & $\begin{array}{c}-0.523^{* *} \\
(0.238)\end{array}$ \\
\hline Many competitors & $\begin{array}{c}-0.597 * * * \\
(0.212)\end{array}$ & $\begin{array}{c}-0.420 * * \\
(0.192)\end{array}$ & $\begin{array}{c}-0.525^{* *} \\
(0.237)\end{array}$ \\
\hline Percent female employees & $\begin{array}{c}0.416^{* *} \\
(0.166)\end{array}$ & $\begin{array}{c}0.818 * * * \\
(0.206)\end{array}$ & $\begin{array}{c}0.449 * * \\
(0.176)\end{array}$ \\
\hline Percent part time employees & $\begin{array}{l}-0.006 \\
(0.142)\end{array}$ & $\begin{array}{c}-0.743^{* * *} \\
(0.180)\end{array}$ & $\begin{array}{c}-0.632^{* * *} \\
(0.152)\end{array}$ \\
\hline Percent fixed term employees & $\begin{array}{c}0.486 * * * \\
(0.147)\end{array}$ & $\begin{array}{l}-0.017 \\
(0.171)\end{array}$ & $\begin{array}{c}0.206 \\
(0.154)\end{array}$ \\
\hline Percent temporary agency employees & $\begin{array}{c}0.380 \\
(0.354)\end{array}$ & $\begin{array}{c}0.515 \\
(0.345)\end{array}$ & $\begin{array}{c}0.256 \\
(0.368)\end{array}$ \\
\hline Percent of workers who separated last year & $\begin{array}{c}0.109 \\
(0.308)\end{array}$ & $\begin{array}{l}-0.284 \\
(0.417)\end{array}$ & $\begin{array}{l}-0.488 \\
(0.332)\end{array}$ \\
\hline Percent of workers who quitted last year & $\begin{array}{c}-0.523 * * \\
(0.214)\end{array}$ & $\begin{array}{c}0.178 \\
(0.285)\end{array}$ & $\begin{array}{c}0.146 \\
(0.221)\end{array}$ \\
\hline Percent of employees more than 50 years old & $\begin{array}{c}-0.900^{* * *} \\
(0.210)\end{array}$ & $\begin{array}{c}0.331 \\
(0.257)\end{array}$ & $\begin{array}{c}-0.620 * * * \\
(0.218)\end{array}$ \\
\hline Percent of employees between 18 and 21 years old & $\begin{array}{c}0.439 \\
(0.277)\end{array}$ & $\begin{array}{c}0.900 * * \\
(0.383)\end{array}$ & $\begin{array}{l}-0.442 \\
(0.292)\end{array}$ \\
\hline Cutoff 1 & $\begin{array}{c}-1.744 * * * \\
(0.322)\end{array}$ & $\begin{array}{c}-1.587 * * * \\
(0.348)\end{array}$ & $\begin{array}{c}-1.805^{* * * *} \\
(0.361)\end{array}$ \\
\hline Cutoff 2 & $\begin{array}{c}-1.071 * * * \\
(0.320)\end{array}$ & $\begin{array}{c}-0.881 * * \\
(0.346)\end{array}$ & $\begin{array}{c}-1.554 * * * \\
(0.360)\end{array}$ \\
\hline Cutoff 3 & $\begin{array}{c}-0.692 * * \\
(0.319)\end{array}$ & $\begin{array}{l}-0.448 \\
(0.345)\end{array}$ & $\begin{array}{c}-0.831^{* *} \\
(0.359)\end{array}$ \\
\hline Cutoff 4 & $\begin{array}{l}-0.414 \\
(0.319)\end{array}$ & $\begin{array}{l}-0.214 \\
(0.345)\end{array}$ & $\begin{array}{c}0.141 \\
(0.358)\end{array}$ \\
\hline Cutoff 5 & $\begin{array}{l}-0.185 \\
(0.319)\end{array}$ & $\begin{array}{c}0.031 \\
(0.346)\end{array}$ & $\begin{array}{c}0.737 * * \\
(0.359)\end{array}$ \\
\hline Cutoff 6 & $\begin{array}{c}0.166 \\
(0.319)\end{array}$ & $\begin{array}{c}0.388 \\
(0.346)\end{array}$ & --- \\
\hline Log-likelihood & -2238.12 & -2028.45 & -1834.09 \\
\hline Observations & 1,297 & 1,208 & 1,163 \\
\hline Industry dummies & Yes & Yes & Yes \\
\hline Region dummies & Yes & Yes & Yes \\
\hline Occupational composition & Yes & Yes & Yes \\
\hline Largest occupational group dummies & Yes & Yes & Yes \\
\hline Missing dummies & Yes & Yes & Yes \\
\hline
\end{tabular}

Notes: For information on the sample, see Notes in Table A1 in the Appendix. The estimation method is an ordered probit model. Entries are coefficients weighted using establishment weights and robust standard errors are in parentheses. In column 1 the dependent variable "COTHJOB" captures the proportion of people in the largest non-managerial occupational group who are formally trained to do jobs other than their own. In column 2 the dependent variable "COFFJOB" captures the proportion of experienced people in the largest non-managerial occupational group that have been given time off from their normal daily work duties to undertake training over the past 12 months. In columns 3, the dependent variable "CTRAIN" captures if any training (i.e. "COFFJOB" is positive), on average how many days of training did experienced employees in the largest non-managerial occupational group undertake over the past 12 months. We recoded those managers who replied "None (0\%)" in COFFJOB to "No time" in CTRAIN. Numbers of observations differ across columns because the definition of each dependent variable differs and each dependent variable has different missing observations. We re-estimated all three models using the sample with the fewer number of observations (i.e. column 3) and results were robust. 'Few competitors' equals to five or less competitors. The omitted category is 'No Competitors'. Other controls not reported here, but whose estimates are available upon request, are: eleven industry dummies (omitted category other community services), ten region dummies (omitted category Yorkshire and Humberside), percentages of eight occupational groups (managerial, professional, technical, sales, operative/assembly, clerical/secretarial, craft/skilled manual, personal services, omitted category percentage of routine/unskilled staff), and seven dummies for the largest occupational group in the establishment (omitted category if the largest occupational group is routine/unskilled workers). In addition, dummy variables for missing observations on each control variable (if the control has missing observations) are included in the estimation. Estimated coefficients of few and many competitors are not significantly different from each other. Levels of significance: *** $\mathrm{p}<0.01$, ** $\mathrm{p}<0.05$, * $\mathrm{p}<0.1$. “--” not relevant. 
Table 2. Robustness Check, Differing Control Vectors, WERS 2011

\begin{tabular}{|c|c|c|c|c|}
\hline & $\begin{array}{c}(1) \\
\text { COTHJOB }\end{array}$ & $\begin{array}{c}(2) \\
\text { COTHJOB }\end{array}$ & $\begin{array}{c}\text { (3) } \\
\text { СОТНЈОВ }\end{array}$ & $\begin{array}{c}(4) \\
\text { COTHJOB }\end{array}$ \\
\hline Few competitors & $\begin{array}{c}-0.579 * * * \\
(0.213)\end{array}$ & $\begin{array}{c}-0.601 * * * \\
(0.215)\end{array}$ & $\begin{array}{c}-0.579 * * * \\
(0.217)\end{array}$ & $\begin{array}{c}-0.654^{* * *} \\
(0.218)\end{array}$ \\
\hline Many competitors & $\begin{array}{c}-0.597 * * * \\
(0.212)\end{array}$ & $\begin{array}{c}-0.619 * * * \\
(0.215)\end{array}$ & $\begin{array}{c}-0.601 * * * \\
(0.217)\end{array}$ & $\begin{array}{c}-0.669 * * * \\
(0.217)\end{array}$ \\
\hline Percent female employees & $\begin{array}{c}0.416^{* *} \\
(0.166)\end{array}$ & $\begin{array}{c}0.394^{* *} \\
(0.168)\end{array}$ & $\begin{array}{c}0.426 * * \\
(0.170)\end{array}$ & $\begin{array}{c}0.465 * * * \\
(0.172)\end{array}$ \\
\hline Percent part time employees & $\begin{array}{l}-0.006 \\
(0.142)\end{array}$ & $\begin{array}{c}0.001 \\
(0.145)\end{array}$ & $\begin{array}{l}-0.024 \\
(0.145)\end{array}$ & $\begin{array}{c}-0.004 \\
(0.146)\end{array}$ \\
\hline Percent fixed term employees & $\begin{array}{c}0.486 * * * \\
(0.147)\end{array}$ & $\begin{array}{c}0.558 * * * \\
(0.149)\end{array}$ & $\begin{array}{c}0.595^{* * *} \\
(0.149)\end{array}$ & $\begin{array}{c}0.643^{* * *} \\
(0.150)\end{array}$ \\
\hline Percent temporary agency employees & $\begin{array}{c}0.380 \\
(0.354)\end{array}$ & $\begin{array}{c}0.271 \\
(0.357)\end{array}$ & $\begin{array}{c}0.299 \\
(0.359)\end{array}$ & $\begin{array}{c}0.373 \\
(0.361)\end{array}$ \\
\hline Percent of workers who separated last year & $\begin{array}{c}0.109 \\
(0.308)\end{array}$ & $\begin{array}{c}0.121 \\
(0.310)\end{array}$ & $\begin{array}{c}0.095 \\
(0.314)\end{array}$ & $\begin{array}{c}0.092 \\
(0.316)\end{array}$ \\
\hline Percent of workers who quitted last year & $\begin{array}{c}-0.523^{* *} \\
(0.214)\end{array}$ & $\begin{array}{c}-0.573^{* * *} \\
(0.216)\end{array}$ & $\begin{array}{c}-0.509^{* *} \\
(0.219)\end{array}$ & $\begin{array}{c}-0.461^{* *} \\
(0.221)\end{array}$ \\
\hline Percent of employees more than 50 years old & $\begin{array}{c}-0.900^{* * *} \\
(0.210)\end{array}$ & $\begin{array}{c}-0.996^{* * * *} \\
(0.210)\end{array}$ & $\begin{array}{c}-0.995^{* * *} \\
(0.210)\end{array}$ & $\begin{array}{c}-0.995^{* * *} \\
(0.210)\end{array}$ \\
\hline Percent of employees between 18 and 21 years old & $\begin{array}{c}0.439 \\
(0.277)\end{array}$ & $\begin{array}{l}0.546^{*} \\
(0.279)\end{array}$ & $0.500^{*}$ & $\begin{array}{c}0.423 \\
(0.283)\end{array}$ \\
\hline Log number of employees & & $\begin{array}{l}0.082^{*} \\
(0.043)\end{array}$ & $\begin{array}{c}0.061 \\
(0.046)\end{array}$ & $\begin{array}{c}0.052 \\
(0.047)\end{array}$ \\
\hline Log number of years establishment has been in operation & & $\begin{array}{l}0.033^{*} \\
(0.018)\end{array}$ & $\begin{array}{l}0.034^{*} \\
(0.018)\end{array}$ & $\begin{array}{c}0.029 \\
(0.018)\end{array}$ \\
\hline Establishment produces different products or services & & $\begin{array}{c}0.409 * * * \\
(0.069)\end{array}$ & $\begin{array}{c}0.407 * * * \\
(0.069)\end{array}$ & $\begin{array}{c}0.405^{* * *} \\
(0.069)\end{array}$ \\
\hline Multi-establishment (part of a larger organization) & & $\begin{array}{l}0.133^{*} \\
(0.071)\end{array}$ & $\begin{array}{c}0.104 \\
(0.074)\end{array}$ & $\begin{array}{c}0.084 \\
(0.075)\end{array}$ \\
\hline Percent of employees who belong to a trade union & & $\begin{array}{l}0.342^{*} \\
(0.206)\end{array}$ & $\begin{array}{c}0.280 \\
(0.209)\end{array}$ & $\begin{array}{c}0.248 \\
(0.211)\end{array}$ \\
\hline Personality/attitude test when filling vacancies & & & $\begin{array}{l}-0.044 \\
(0.078)\end{array}$ & $\begin{array}{l}-0.050 \\
(0.078)\end{array}$ \\
\hline Performance/competency test when filling vacancies & & & $\begin{array}{c}0.150^{* *} \\
(0.069)\end{array}$ & $\begin{array}{c}0.140^{* *} \\
(0.069)\end{array}$ \\
\hline Problem solving groups/quality circles & & & $\begin{array}{c}0.040 \\
(0.086)\end{array}$ & $\begin{array}{c}0.029 \\
(0.087)\end{array}$ \\
\hline System designed to minimize inventories, supplies, work in progress & & & $\begin{array}{l}0.138^{*} \\
(0.074)\end{array}$ & $\begin{array}{l}0.137^{*} \\
(0.075)\end{array}$ \\
\hline Joint consultative committees/work councils & & & $\begin{array}{c}0.020 \\
(0.109)\end{array}$ & $\begin{array}{c}0.065 \\
(0.110)\end{array}$ \\
\hline Payment by result & & & & $\begin{array}{l}0.138^{*} \\
(0.082)\end{array}$ \\
\hline Merit pay & & & & $\begin{array}{c}0.190^{* *} \\
(0.094)\end{array}$ \\
\hline Profit related pay & & & & $\begin{array}{c}0.214^{* * *} \\
(0.070)\end{array}$ \\
\hline Employee share scheme & & & & $\begin{array}{l}-0.092 \\
(0.104)\end{array}$ \\
\hline Cutoff 1 & $\begin{array}{c}-1.744 * * * \\
(0.322)\end{array}$ & $\begin{array}{c}-0.905^{* *} \\
(0.373)\end{array}$ & $\begin{array}{c}-0.883^{* *} \\
(0.378)\end{array}$ & $\begin{array}{c}-0.895 * * \\
(0.379)\end{array}$ \\
\hline Cutoff 2 & $\begin{array}{c}-1.071 * * * \\
(0.320)\end{array}$ & $\begin{array}{l}-0.204 \\
(0.373)\end{array}$ & $\begin{array}{l}-0.179 \\
(0.379)\end{array}$ & $\begin{array}{l}-0.183 \\
(0.379)\end{array}$ \\
\hline Cutoff 3 & $\begin{array}{c}-0.692 * * \\
(0.319)\end{array}$ & $\begin{array}{c}0.185 \\
(0.373)\end{array}$ & $\begin{array}{c}0.214 \\
(0.378)\end{array}$ & $\begin{array}{c}0.214 \\
(0.379)\end{array}$ \\
\hline Cutoff 4 & $\begin{array}{l}-0.414 \\
(0.319)\end{array}$ & $\begin{array}{c}0.467 \\
(0.372)\end{array}$ & $\begin{array}{c}0.498 \\
(0.378)\end{array}$ & $\begin{array}{c}0.500 \\
(0.379)\end{array}$ \\
\hline Cutoff 5 & $\begin{array}{l}-0.185 \\
(0.319)\end{array}$ & $\begin{array}{l}0.696^{*} \\
(0.372)\end{array}$ & $\begin{array}{l}0.728^{*} \\
(0.377)\end{array}$ & $\begin{array}{l}0.731^{*} \\
(0.378)\end{array}$ \\
\hline Cutoff 6 & $\begin{array}{c}0.166 \\
(0.319)\end{array}$ & $\begin{array}{c}1.045^{* * *} \\
(0.372)\end{array}$ & $\begin{array}{c}1.079 * * * \\
(0.377)\end{array}$ & $\begin{array}{c}1.084^{* * *} \\
(0.378)\end{array}$ \\
\hline Log-likelihood & -2238.12 & -2208.29 & -2203.14 & -2191.83 \\
\hline Observations & 1,297 & 1,297 & 1,297 & 1,297 \\
\hline Industry dummies & Yes & Yes & Yes & Yes \\
\hline Region dummies & Yes & Yes & Yes & Yes \\
\hline Occupational composition & Yes & Yes & Yes & Yes \\
\hline Largest occupational group dummies & Yes & Yes & Yes & Yes \\
\hline Missing dummies & Yes & Yes & Yes & Yes \\
\hline
\end{tabular}


Table 3. Cross Training and Product Market Competition: Panel data 1998-2004 and 2004-2011

\begin{tabular}{|c|c|c|c|c|c|c|c|c|}
\hline & \multicolumn{4}{|c|}{ Panel 1998-2004 } & \multicolumn{4}{|c|}{ Panel 2004-2011 } \\
\hline & (1) & (2) & (3) & (4) & (5) & (6) & (7) & (8) \\
\hline & $\begin{array}{l}\text { Ordered Probit } \\
\text { Without FE }\end{array}$ & $\begin{array}{l}\text { OLS without } \\
\text { FE }\end{array}$ & OLS with FE & $\begin{array}{l}\text { Poisson } \\
\text { with FE }\end{array}$ & $\begin{array}{l}\text { Ordered Probit } \\
\text { Without FE }\end{array}$ & $\begin{array}{l}\text { OLS without } \\
\text { FE }\end{array}$ & OLS with FE & $\begin{array}{l}\text { Poisson } \\
\text { with FE }\end{array}$ \\
\hline \multirow{2}{*}{ Few competitors } & $-0.564 * * *$ & $-0.284 * * *$ & $-0.401 *$ & $-0.517 * *$ & $-0.374 *$ & $-0.224 * *$ & $-0.423 * *$ & $-0.468 * *$ \\
\hline & $(0.184)$ & $(0.102)$ & $(0.231)$ & $(0.222)$ & $(0.220)$ & $(0.089)$ & $(0.190)$ & $(0.237)$ \\
\hline \multirow{2}{*}{ Many competitors } & $-0.548 * * *$ & $-0.314 * * *$ & $-0.494 * *$ & $-0.554 * *$ & $-0.520 * *$ & $-0.229 * * *$ & $-0.437 * *$ & $-0.460 * *$ \\
\hline & $(0.183)$ & $(0.098)$ & $(0.232)$ & $(0.221)$ & $(0.221)$ & $(0.086)$ & $(0.190)$ & $(0.213)$ \\
\hline R-squared & --- & 0.289 & 0.680 & --- & --- & 0.218 & 0.661 & --- \\
\hline Log-likelihood & -1613.81 & --- & --- & -585.98 & -1208.52 & --- & --- & -457.87 \\
\hline Observations & 940 & 940 & 940 & 940 & 710 & 710 & 710 & 710 \\
\hline Industry dummies & Yes & Yes & No & No & Yes & Yes & No & No \\
\hline Region dummies & Yes & Yes & No & No & Yes & Yes & No & No \\
\hline Workforce characteristics & Yes & Yes & Yes & Yes & Yes & Yes & Yes & Yes \\
\hline Occupational composition & Yes & Yes & Yes & Yes & Yes & Yes & Yes & Yes \\
\hline $\begin{array}{l}\text { Largest occupational group } \\
\text { dummies }\end{array}$ & Yes & Yes & Yes & Yes & Yes & Yes & Yes & Yes \\
\hline Missing dummies & Yes & Yes & Yes & Yes & Yes & Yes & Yes & Yes \\
\hline
\end{tabular}

Notes: The sample consists of a balanced panel of trading sector establishments with 10 or more employees. In the $1998-2004$ panel we observe 470 establishments generating 940 observations. In the 2004-2011 panel we observe 355 establishments generating 710 observations. For information on the sample see Notes in Table A1 in the Appendix. 'Few competitors' equals to five or less competitors. The omitted category is 'No Competitors'. For reasons of brevity, we only present estimates of the two competition variables. Other controls are those shown in Table 1 (plus a year dummy) and their estimates are available upon request. Standard errors are in parentheses. They are clustered at establishment cells in columns $1,2,5$ and 6 , and at industry cells in columns 3,4,7 and 8 Levels of significance: *** $\mathrm{p}<0.01$, ** $\mathrm{p}<0.05$, * $\mathrm{p}<0.1$. “---” not available. 
Table 4. Alternative Measures of Training, Panel Fixed Effect Estimates

\begin{tabular}{lccc}
\hline & Panel 1998-2004 & \multicolumn{2}{c}{ Panel 2004-2011 } \\
& $(1)$ & $(2)$ & $(3)$ \\
\hline & COFFJOB & COFFJOB & CTRAIN \\
Few competitors & $-0.637^{*}$ & $-0.712^{*}$ & $-0.857^{*}$ \\
& $(0.342)$ & $(0.416)$ & $(0.504)$ \\
Many competitors & $-0.699^{*}$ & $-0.728^{*}$ & $-0.995^{*}$ \\
& $(0.368)$ & $(0.410)$ & $(0.568)$ \\
Observations & 940 & 710 & 710 \\
Industry dummies & No & No & No \\
Region dummies & No & No & No \\
Workforce characteristics & Yes & Yes & Yes \\
Occupational composition & Yes & Yes & Yes \\
Largest occupational group & Yes & Yes & Yes \\
dummies & & & \\
Missing dummies & Yes & Yes & Yes \\
\hline Notes. The estimation method is OLS with establishment fixed effects. We recoded those managers who replied “None \\
(0\%)" in COFFOB to "No time" in CTRAIN. The variable CTRAIN is not available in the 1998-2004 panel. Standard \\
errors are in parentheses and are clustered at industry cells. Levels of significance: ${ }^{* * *} \mathrm{p}<0.01,{ }^{* *} \mathrm{p}<0.05,{ }^{*} \mathrm{p}<0.1$.
\end{tabular}


Table 5. Objective Measures of Competition, Panel Data

$$
\text { (1) }
$$

Panel 1998-2004

$$
\text { (2) }
$$

\begin{tabular}{|c|c|c|c|c|}
\hline & COTHJOB & СОTHJOB & COTHJOB & \\
\hline \multirow{2}{*}{ Concentration Index } & $0.003^{* * *}$ & $0.002 * *$ & $0.006^{* * *}$ & $0.005^{* *}$ \\
\hline & $(0.001)$ & $(0.001)$ & $(0.001)$ & $(0.002)$ \\
\hline R-squared & 0.195 & 0.809 & 0.130 & 0.687 \\
\hline Observations & 885 & 885 & 688 & 688 \\
\hline Industry dummies & Yes & No & Yes & No \\
\hline Region dummies & Yes & No & Yes & No \\
\hline Workforce characteristics & Yes & Yes & Yes & Yes \\
\hline Occupational composition & Yes & Yes & Yes & Yes \\
\hline Largest occupational group dummies & Yes & Yes & Yes & Yes \\
\hline Missing dummies & Yes & Yes & Yes & Yes \\
\hline
\end{tabular}

\begin{tabular}{|c|c|c|c|c|}
\hline \multirow{3}{*}{ Concentration Index } & COTHJOB & СОTHJOB & COTHJOB & \\
\hline & $0.003 * * *$ & $0.002 * *$ & $0.006 * * *$ & $0.005^{* *}$ \\
\hline & $(0.001)$ & $(0.001)$ & $(0.001)$ & $(0.002)$ \\
\hline R-squared & 0.195 & 0.809 & 0.130 & 0.687 \\
\hline Observations & 885 & 885 & 688 & 688 \\
\hline Industry dummies & Yes & No & Yes & No \\
\hline Region dummies & Yes & No & Yes & No \\
\hline Workforce characteristics & Yes & Yes & Yes & Yes \\
\hline Occupational composition & Yes & Yes & Yes & Yes \\
\hline Largest occupational group dummies & Yes & Yes & Yes & Yes \\
\hline Missing dummies & Yes & Yes & Yes & Yes \\
\hline
\end{tabular}

COTHJOB fixed effects

Missing dummies

$$
\text { Yes }
$$

$\begin{array}{cc}0.003^{* * *} & 0.002^{* *} \\ (0.001) & (0.001) \\ 0.195 & 0.809 \\ 885 & 885 \\ \text { Yes } & \text { No } \\ \text { Yes } & \text { No } \\ \text { Yes } & \text { Yes } \\ \text { Yes } & \text { Yes } \\ \text { Yes } & \text { Yes } \\ \text { Yes } & \text { Yes }\end{array}$

that year. For reasons of brevity we report only estimates of the variable of interest. Other contrut produced by the top five firms within an industry as a proportion of total industry output for variables (few and many competitors). The estimation method is an OLS in columns 1 and 3 and an OLS with establishment fixed effects in columns 2 and 4 . Standard errors are in parentheses.

They are clustered at establishment cells in columns 1 and 3, and at industry cells in columns 2 and 4 . The number of observations is less for both panels than those reported in Table 3 . We lose 55 observations when merging in the concentration index for the 1998-2004 panel and 22 when merging in the concentration index for the $2004-2011$ panel. Levels of significance: $* * *$ p $<0.01$, $* * \mathrm{p}<0.05, * \mathrm{p}<0.1$. 
Table 6. Instrumental Variables (IV) Results from the Panel 1998-2004

\begin{tabular}{|c|c|c|c|c|c|c|}
\hline & \multicolumn{3}{|c|}{ Without establishment fixed effects } & \multicolumn{3}{|c|}{ With establishment fixed effects } \\
\hline & \multicolumn{2}{|c|}{ First stage } & \multirow{2}{*}{$\begin{array}{c}\text { Second stage } \\
(3)\end{array}$} & \multicolumn{2}{|c|}{ First stage } & \multirow{2}{*}{$\begin{array}{c}\text { Second stage } \\
(6)\end{array}$} \\
\hline & (1) & (2) & & (4) & (5) & \\
\hline & Few competitors & Many competitors & Training (COTHJOB) & Few competitors & Many competitors & Training (COTHJOB) \\
\hline Few competitors & --- & --- & $\begin{array}{c}-1.351 * * \\
(0.597)\end{array}$ & --- & --- & $\begin{array}{c}-2.438 * * * \\
(0.883)\end{array}$ \\
\hline Many competitors & --- & --- & $\begin{array}{c}-1.405^{* *} \\
(0.596)\end{array}$ & --- & --- & $\begin{array}{l}-2.652 * * * \\
(0.921)\end{array}$ \\
\hline Instrument for few competitors & $\begin{array}{l}11.070 * * * \\
(0.653)\end{array}$ & $\begin{array}{c}-3.497 * * * \\
(0.693)\end{array}$ & -- & $\begin{array}{l}12.088 * * * \\
(0.884)\end{array}$ & $\begin{array}{l}-4.316^{* * *} \\
(0.615)\end{array}$ & --- \\
\hline Instrument for many competitors & $\begin{array}{l}-1.156 * * * \\
(0.395)\end{array}$ & $\begin{array}{l}5.805^{* * *} \\
(0.419)\end{array}$ & --- & $\begin{array}{l}-0.199 \\
(0.567)\end{array}$ & $\begin{array}{c}5.422 * * * \\
(0.960)\end{array}$ & --- \\
\hline F-test of excluded instruments & $\begin{array}{c}24.90 \\
\text { p-value }=0.0000\end{array}$ & $\begin{array}{c}18.90 \\
\text { p-value }=0.0005\end{array}$ & --- & $\begin{array}{c}22.93 \\
\text { p-value }=0.0000\end{array}$ & $\begin{array}{c}17.98 \\
\text { p-value }=0.0000\end{array}$ & --- \\
\hline $\begin{array}{l}\text { Angrist-Pischke multivariate F-test of } \\
\text { excluded instruments }\end{array}$ & $\begin{array}{c}16.06 \\
\text { p-value }=0.0012\end{array}$ & $\begin{array}{c}14.20 \\
\text { p-value }=0.0098\end{array}$ & --- & $\begin{array}{c}15.90 \\
\text { p-value }=0.0045\end{array}$ & $\begin{array}{c}14.19 \\
\text { p-value }=0.0152\end{array}$ & --- \\
\hline $\begin{array}{l}\text { Underidentification test (Kleibergen- } \\
\text { Paap rk LM statistic) }\end{array}$ & --- & --- & $\begin{array}{c}19.502 \\
p \text {-value }=0.0001\end{array}$ & F -- & --- & $\begin{array}{c}12.082 \\
\text { p-value }=0.0005\end{array}$ \\
\hline $\begin{array}{l}\text { Weak identification test (Cragg-Donald } \\
\text { Wald F statistic) }\end{array}$ & --- & --- & 108.722 & --- & --- & 57.760 \\
\hline Observations & 940 & 940 & 940 & 940 & 940 & 940 \\
\hline Industry dummies & Yes & Yes & Yes & No & No & No \\
\hline Region dummies & Yes & Yes & Yes & No & No & No \\
\hline Workforce characteristics & Yes & Yes & Yes & Yes & Yes & Yes \\
\hline Occupational composition & Yes & Yes & Yes & Yes & Yes & Yes \\
\hline Largest occupational group dummies & Yes & Yes & Yes & Yes & Yes & Yes \\
\hline Missing dummies & Yes & Yes & Yes & Yes & Yes & Yes \\
\hline
\end{tabular}

Notes. 'Few Competitors' and 'Many Competitors' are the endogenous variables. The instruments are the proportion of establishments with few or many competitors in industry cells after removing the own establishment from the cell. The estimation method is a 2SLS. Entries are coefficients weighted using establishment weights. Standard errors are clustered at establishment cells in columns 1,2 and 3 , and at industry cells in columns 4,5 and 6 .. For reasons of brevity we only report estimates of the variables of interest. Levels of significance: $* * * p<0.01$, $* * p<0.05$, *p<0.1. “---” not included or relevant. 
Table 7. Instrumental Variables (IV) Results from the Panel 2004-2011

\begin{tabular}{|c|c|c|c|c|c|c|}
\hline & \multicolumn{3}{|c|}{ Without establishment fixed effects } & \multicolumn{3}{|c|}{ With establishment fixed effects } \\
\hline & \multicolumn{2}{|c|}{ First stage } & \multirow{2}{*}{$\frac{\text { Second stage }}{(3)}$} & \multicolumn{2}{|c|}{ First stage } & \multirow{2}{*}{$\frac{\text { Second stage }}{(6)}$} \\
\hline & (1) & (2) & & (4) & (5) & \\
\hline & Few competitors & Many competitors & Training (COTHJOB) & Few competitors & Many competitors & Training (COTHJOB) \\
\hline Few competitors & --- & --- & $\begin{array}{c}-1.147^{* *} \\
(0.564)\end{array}$ & --- & --- & $\begin{array}{c}-1.901^{* *} \\
(0.743)\end{array}$ \\
\hline Many competitors & --- & --- & $\begin{array}{c}-1.463^{* *} \\
(0.607)\end{array}$ & --- & --- & $\begin{array}{c}-1.931^{* *} \\
(0.843)\end{array}$ \\
\hline Instrument for few competitors & $\begin{array}{l}13.948^{* * *} \\
(0.618)\end{array}$ & $\begin{array}{c}-4.475^{* * *} \\
(1.018)\end{array}$ & --- & $\begin{array}{l}15.555^{* * *} \\
(0.824)\end{array}$ & $\begin{array}{l}-3.095^{* * *} \\
(0.852)\end{array}$ & --- \\
\hline Instrument for many competitors & $\begin{array}{c}-2.640^{* * *} \\
(0.619)\end{array}$ & $\begin{array}{c}5.238^{* * *} \\
(1.196)\end{array}$ & --- & $\begin{array}{c}-3.959 * * * \\
(0.719)\end{array}$ & $\begin{array}{c}6.841^{* * *} \\
(0.977)\end{array}$ & --- \\
\hline F-test of excluded instruments & $\begin{array}{c}23.23 \\
\text { p-value }=0.0003\end{array}$ & $\begin{array}{c}17.68 \\
\text { p-value }=0.0011\end{array}$ & --- & $\begin{array}{c}32.80 \\
\text { p-value }=0.0000\end{array}$ & $\begin{array}{c}25.46 \\
\text { p-value }=0.0000\end{array}$ & --- \\
\hline $\begin{array}{l}\text { Angrist-Pischke multivariate F-test of } \\
\text { excluded instruments }\end{array}$ & $\begin{array}{c}15.58 \\
\text { p-value }=0.0045\end{array}$ & $\begin{array}{c}13.87 \\
\text { p-value }=0.0098\end{array}$ & --- & $\begin{array}{c}22.19 \\
\text { p-value }=0.0000\end{array}$ & $\begin{array}{c}18.75 \\
\text { p-value }=0.0008\end{array}$ & --- \\
\hline $\begin{array}{l}\text { Underidentification test (Kleibergen-Paap } \\
\text { rk LM statistic) }\end{array}$ & --- & --- & $\begin{array}{c}15.385 \\
\text { p-value }=0.0014\end{array}$ & --- & --- & $\begin{array}{c}14.806 \\
\text { p-value }=0.0001\end{array}$ \\
\hline $\begin{array}{l}\text { Weak identification test (Cragg-Donald } \\
\text { Wald F statistic) }\end{array}$ & --- & --- & 205.494 & --- & --- & $\begin{array}{c}83.657 \\
\text { p-value }=0.0000\end{array}$ \\
\hline Observations & 710 & 710 & 710 & 710 & 710 & 710 \\
\hline Industry dummies & Yes & Yes & Yes & No & No & No \\
\hline Region dummies & Yes & Yes & Yes & No & No & No \\
\hline Workforce characteristics & Yes & Yes & Yes & Yes & Yes & Yes \\
\hline Occupational composition & Yes & Yes & Yes & Yes & Yes & Yes \\
\hline Largest occupational group dummies & Yes & Yes & Yes & Yes & Yes & Yes \\
\hline Missing dummies & Yes & Yes & Yes & Yes & Yes & Yes \\
\hline
\end{tabular}




\section{APPENDIX TABLES}

Table A1. Distribution of Cross Training “COTHJOB”

\begin{tabular}{lccccc}
\hline & 1998 & 2004 & 2011 & $\begin{array}{c}\text { Panel } \\
1998-2004\end{array}$ & $\begin{array}{c}\text { Panel } \\
2004-2011\end{array}$ \\
\hline None (0\%) & 0.322 & 0.334 & 0.288 & 0.278 & 0.304 \\
& $(0.467)$ & $(0.472)$ & $(0.453)$ & $(0.449)$ & $(0.460)$ \\
Just a few (1-19\%) & {$[339]$} & {$[297]$} & {$[277]$} & {$[196]$} & {$[162]$} \\
& 0.237 & 0.226 & 0.237 & 0.246 & 0.257 \\
Some (20-39\%) & $(0.425)$ & $(0.419)$ & $(0.426)$ & $(0.431)$ & $(0.437)$ \\
& {$[414]$} & {$[376]$} & {$[376]$} & {$[264]$} & {$[211]$} \\
& 0.106 & 0.148 & 0.133 & 0.142 & 0.128 \\
Around half (40-59\%) & $(0.307)$ & $(0.356)$ & $(0.339)$ & $(0.349)$ & $(0.335)$ \\
& {$[238]$} & {$[222]$} & {$[216]$} & {$[174]$} & {$[119]$} \\
Most (60-79\%) & 0.071 & 0.092 & 0.087 & 0.104 & 0.085 \\
& {$[0.256)$} & $(0.289)$ & $(0.282)$ & $(0.307)$ & $(0.278)$ \\
Almost all (80-99\%) & {$[139]$} & {$[138]$} & {$[134]$} & {$[98]$} & {$[70]$} \\
& 0.062 & 0.066 & 0.061 & 0.049 & 0.067 \\
All (100\%) & {$[0.241)$} & $(0.248)$ & $(0.240)$ & $(0.216)$ & $(0.250)$ \\
& 0.079 & {$[91]$} & {$[89]$} & {$[86]$} & {$[54]$} \\
Total observations & 0.055 & 0.076 & 0.110 & 0.076 \\
& {$[100]$} & {$[0.227)$} & $(0.264)$ & $(0.314)$ & $(0.265)$ \\
& 0.123 & 0.079 & {$[87]$} & {$[72]$} & {$[47]$} \\
& $(0.328)$ & $(0.269)$ & $(0.322)$ & $(0.254)$ & 0.084 \\
& {$[107]$} & {$[78]$} & {$[118]$} & {$[50]$} & {$[47]$} \\
& 1,464 & 1,263 & 1,297 & 940 & 710 \\
\hline
\end{tabular}

Notes: The samples for the three cross sections consist of trading sector establishments with 10 or more employees. 'Trading' implies that establishments provide goods and services to the general public or to other organisations. We also exclude establishments where the largest occupational group is managers or senior officials as the dependent variable does not apply to this group. For the two panel datasets we apply the same restrictions as in the cross sections and we keep establishments observed twice. Thus, in the 1998-2004 (2004-2011) balanced panel we have 470 (355) establishments generating 940 (710) observations. Standard deviations are in parentheses and numbers of observations are in square brackets. Means are weighted using establishment weights and sum to 100 .

Table A2. Distribution of the Number of Competitors Variables

\begin{tabular}{lccccc}
\hline & 1998 & 2004 & 2011 & $\begin{array}{c}\text { Panel } \\
1998-2004\end{array}$ & $\begin{array}{c}\text { Panel } \\
2004-2011\end{array}$ \\
\hline None/dominates market & 0.065 & 0.054 & 0.022 & 0.019 & 0.040 \\
& $(0.248)$ & $(0.227)$ & $(0.148)$ & $(0.135)$ & $(0.196)$ \\
& {$[130]$} & {$[77]$} & {$[54]$} & {$[44]$} & {$[26]$} \\
Few competitors & 0.320 & 0.368 & 0.401 & 0.302 & 0.330 \\
& $(0.466)$ & $(0.483)$ & $(0.490)$ & $(0.459)$ & $(0.471)$ \\
Many competitors & {$[502]$} & {$[481]$} & {$[493]$} & {$[318]$} & {$[268]$} \\
& 0.614 & 0.577 & 0.576 & 0.679 & 0.630 \\
Total observations & $(0.486)$ & $(0.494)$ & $(0.494)$ & $(0.467)$ & $(0.483)$ \\
& {$[832]$} & {$[705]$} & {$[750]$} & {$[578]$} & {$[416]$} \\
\hline
\end{tabular}

Note: For information on the sample, see Notes in Table A1. 'Few competitors' equals to five or less competitors. Standard deviations are in parentheses and numbers of observations are in square brackets. Means are weighted using establishment weights and sum to 100 . 